\title{
LEVEL II SCOUR ANALYSIS FOR BRIDGE 15 (BRIDTH00220015) on TOWN HIGHWAY 22, crossing DAILEY HOLLOW BRANCH, BRIDGEWATER, VERMONT
}

U.S. Geological Survey Open-File Report 96-403

Prepared in cooperation with

VERMONT AGENCY OF TRANSPORTATION and

FEDERAL HIGHWAY ADMINISTRATION 


\section{LEVEL II SCOUR ANALYSIS FOR BRIDGE 15 (BRIDTH00220015) on TOWN HIGHWAY 22, crossing DAILEY HOLLOW BRANCH, BRIDGEWATER, VERMONT \\ By SCOTT A. OLSON}

U.S. Geological Survey Open-File Report 96-403

Prepared in cooperation with

VERMONT AGENCY OF TRANSPORTATION and

FEDERAL HIGHWAY ADMINISTRATION 


\title{
U.S. DEPARTMENT OF THE INTERIOR BRUCE BABBITT, Secretary
}

\author{
U.S. GEOLOGICAL SURVEY \\ Gordon P. Eaton, Director
}

For additional information write to:

District Chief

U.S. Geological Survey 361 Commerce Way

Pembroke, NH 03275-3718
Copies of this report may be purchased from:

U.S. Geological Survey Earth Science Information Center Open-File Reports Section Box 25286, MS 517 Federal Center

Denver, CO 80225 


\section{CONTENTS}

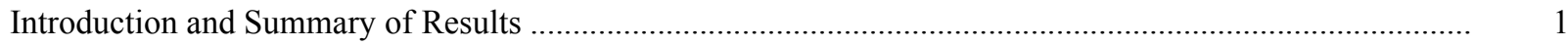

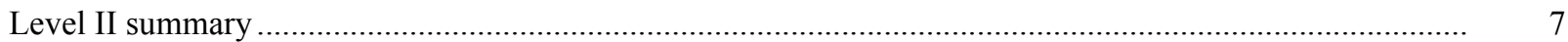

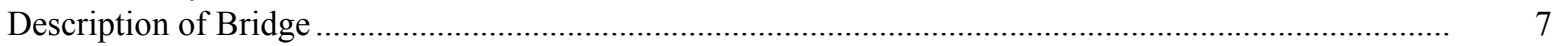

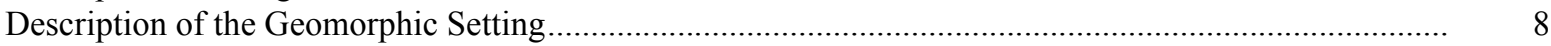

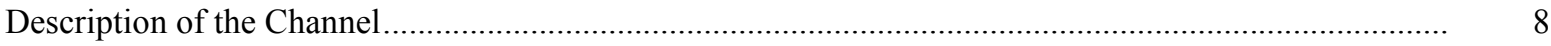

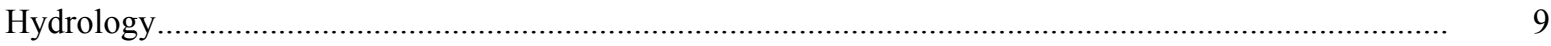

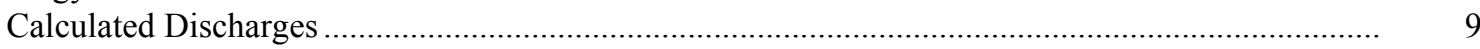

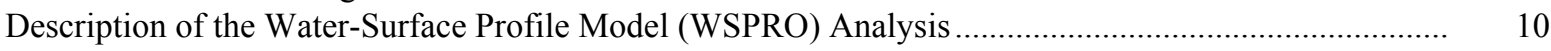

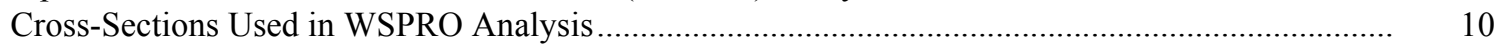

Data and Assumptions Used in WSPRO Model ...................................................................... 11

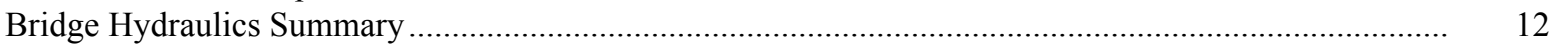

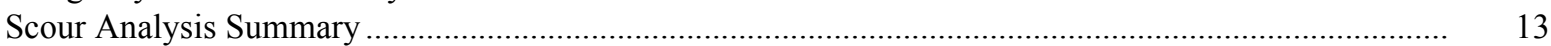

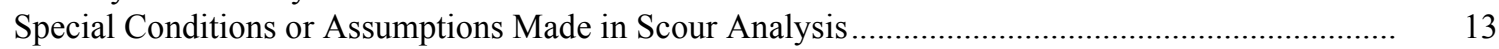

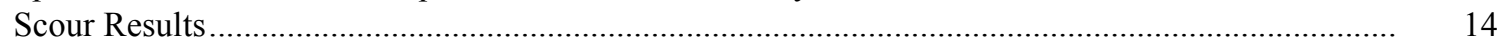

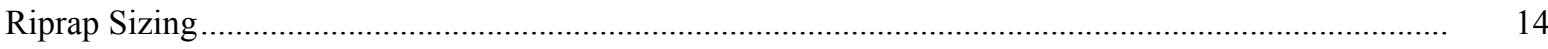

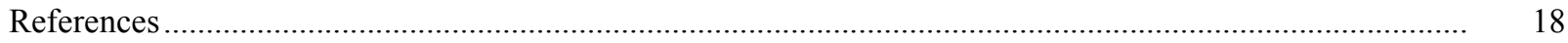

Appendixes:

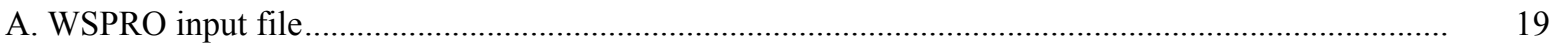

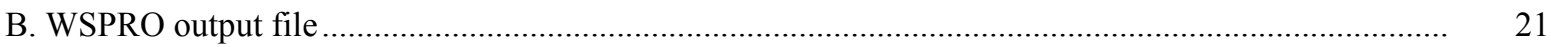

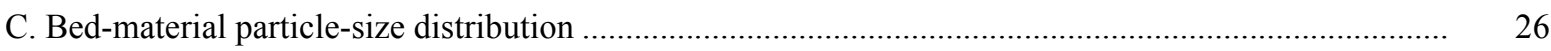

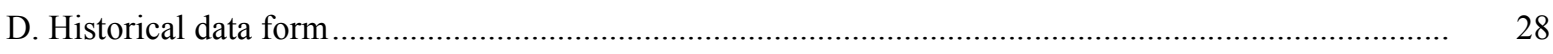

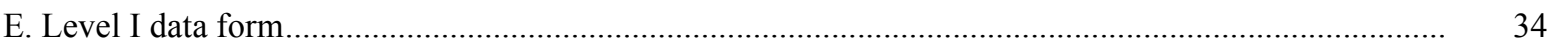

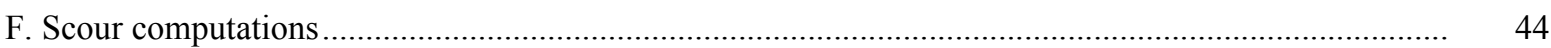

\section{FIGURES}

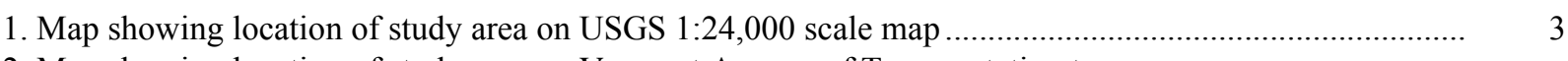

2. Map showing location of study area on Vermont Agency of Transportation town

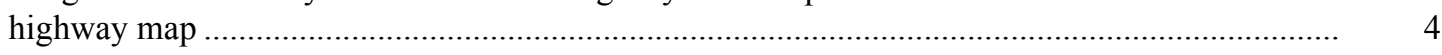

3. Structure BRIDTH00220015 viewed from upstream (November 2, 1994)...........................................

4. Downstream channel viewed from structure BRIDTH00220015 (November 2, 1994)......................... 5

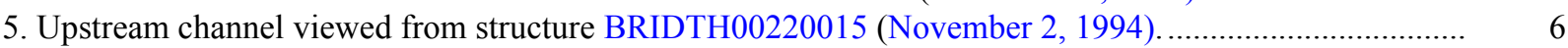

6. Structure BRIDTH00220015 viewed from downstream (November 2, 1994)...................................... 6

7. Water-surface profiles for the 100- and 500-year discharges at structure BRIDTH00220015 on Town Highway 22, crossing Dailey Hollow Branch, Bridgewater, Vermont.

8. Scour elevations for the 100- and 500-year discharges at structure BRIDTH00220015 on Town Highway 22, crossing Dailey Hollow Branch, Bridgewater, Vermont.

\section{TABLES}

1. Remaining footing/pile depth at abutments for the 100-year discharge at structure BRIDTH00220015 on Town Highway 22, crossing Dailey Hollow Branch,

Bridgewater, Vermont.

2. Remaining footing/pile depth at abutments for the 500-year discharge at structure

BRIDTH00220015 on Town Highway 22, crossing Dailey Hollow Branch,

Bridgewater, Vermont.

(

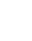

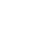

6

.




\begin{tabular}{|c|c|c|}
\hline Multiply & By & To obtain \\
\hline \multicolumn{3}{|c|}{ Length } \\
\hline inch (in.) & 25.4 & millimeter (mm) \\
\hline foot $(\mathrm{ft})$ & 0.3048 & meter $(\mathrm{m})$ \\
\hline mile (mi) & 1.609 & kilometer (km) \\
\hline \multicolumn{3}{|c|}{ Slope } \\
\hline foot per mile ( $\mathrm{ft} / \mathrm{mi})$ & 0.1894 & meter per kilometer $(\mathrm{m} / \mathrm{km})$ \\
\hline \multicolumn{3}{|c|}{ Area } \\
\hline square mile $\left(\mathrm{mi}^{2}\right)$ & 2.590 & square kilometer $\left(\mathrm{km}^{2}\right)$ \\
\hline \multicolumn{3}{|c|}{ Volume } \\
\hline cubic foot $\left(\mathrm{ft}^{3}\right)$ & $\begin{array}{l}0.02832 \\
\text { Velocity and Flow }\end{array}$ & cubic meter $\left(\mathrm{m}^{3}\right)$ \\
\hline foot per second (ft/s) & 0.3048 & meter per second $(\mathrm{m} / \mathrm{s})$ \\
\hline cubic foot per second $\left(\mathrm{ft}^{3} / \mathrm{s}\right)$ & 0.02832 & cubic meter per second $\left(\mathrm{m}^{3} / \mathrm{s}\right)$ \\
\hline $\begin{array}{l}\text { cubic foot per second per } \\
\text { square mile } \\
{\left[\left(\mathrm{ft}^{3} / \mathrm{s}\right) / \mathrm{mi}^{2}\right]}\end{array}$ & 0.01093 & $\begin{array}{l}\text { cubic meter per } \\
\text { second per square } \\
\text { kilometer }\left[\left(\mathrm{m}^{3} / \mathrm{s}\right) / \mathrm{km}^{2}\right]\end{array}$ \\
\hline
\end{tabular}

OTHER ABBREVIATIONS

$\begin{array}{lrlr}\mathrm{BF} & \text { bank full } & \text { LWW } & \text { left wingwall } \\ \mathrm{cfs} & \text { cubic feet per second } & \text { MC } & \text { main channel } \\ \mathrm{D}_{50} & \text { median diameter of bed material } & \text { RAB } & \text { right abutment } \\ \mathrm{DS} & \text { downstream } & \text { RABUT } & \text { face of right abutment } \\ \mathrm{elev} & \text { elevation } & \text { RB } & \text { right bank } \\ \mathrm{f} / \mathrm{p} & \text { flood plain } & \text { ROB } & \text { right overbank } \\ \mathrm{ft} & \text { square feet } & \text { RWW } & \text { right wingwall } \\ \mathrm{ft} / \mathrm{ft} & \text { feet per foot } & \text { TH } & \text { town highway } \\ \mathrm{JCT} & \text { junction } & \text { UB } & \text { under bridge } \\ \mathrm{LAB} & \text { left abutment } & \text { US } & \text { upstream } \\ \mathrm{LABUT} & \text { face of left abutment } & \text { USGS } & \text { United States Geological Survey } \\ \text { LB } & \text { left bank } & \text { VTAOT Vermont Agency of Transportation } \\ \text { LOB } & \text { left overbank } & \text { WSPRO } & \text { water-surface profile model }\end{array}$

In this report, the words "right" and "left" refer to directions that would be reported by an observer facing downstream. Sea level: In this report, "sea level" refers to the National Geodetic Vertical Datum of 1929-- a geodetic datum derived from a general adjustment of the first-order level nets of the United States and Canada, formerly called Sea Level Datum of 1929.

In the appendices, the above abbreviations may be combined. For example, USLB would represent upstream left bank. 


\title{
LEVEL II SCOUR ANALYSIS FOR BRIDGE 15 (BRIDTH00220015) ON TOWN HIGHWAY 22, CROSSING DAILEY HOLLOW BRANCH, BRIDGEWATER, VERMONT
}

\author{
By Scott A. Olson
}

\section{INTRODUCTION AND SUMMARY OF RESULTS}

This report provides the results of a detailed Level II analysis of scour potential at structure BRIDTH00220015 on town highway 22 crossing Dailey Hollow Branch, Bridgewater, Vermont (figures 1-8). A Level II study is a basic engineering analysis of the site, including a quantitative analysis of stream stability and scour (U.S. Department of Transportation, 1993). Results of a Level I scour investigation also are included in Appendix E of this report. A Level I investigation provides a qualitative geomorphic characterization of the study site. Information on the bridge, gleaned from Vermont Agency of Transportation (VTAOT) files, was compiled prior to conducting Level I and Level II analyses and is found in Appendix D.

The site is in the Green Mountain section of the New England physiographic province of central Vermont in the town of Bridgewater. The $1.73-\mathrm{mi}^{2}$ drainage area is a predominantly rural and forested basin. In the vicinity of the study site, the left and right banks have dense tree cover. The upstream right bank of Dailey Hollow Branch is adjacent to town highway 22.

In the study area, Dailey Hollow Branch has a sinuous channel with a slope of approximately $0.035 \mathrm{ft} / \mathrm{ft}$, an average channel top width of $30 \mathrm{ft}$ and an average channel depth of $4 \mathrm{ft}$. The predominant channel bed material is cobble with a median grain size $\left(\mathrm{D}_{50}\right)$ of $108 \mathrm{~mm}(0.354 \mathrm{ft})$. The geomorphic assessment at the time of the Level I and Level II site visit on November 1 and 2, 1994, indicates that the reach is stable.

The town highway 22 crossing of Dailey Hollow Branch is a 22-ft-long, one-lane bridge consisting of one 22-ft. steel-beam span (Vermont Agency of Transportation, written communication, August 24, 1994). The bridge is supported by vertical, concrete abutments with wingwalls. Type-1 stone fill (less than 12 inches diameter) protects the left abutment, but it's condition was reported as eroded. Type- 2 stone fill (less than 36 inches diameter) protects the upstream left wingwall; it's condition was reported as slumping. The channel is skewed approximately 40 degrees to the opening while the opening-skew-to-roadway is 0 degrees. Additional details describing conditions at the site are included in the Level II Summary and Appendices D and E. 
Scour depths and rock rip-rap sizes were computed using the general guidelines described in Hydraulic Engineering Circular 18 (Richardson and others, 1993). Total scour at a highway crossing is comprised of three components: 1) long-term streambed degradation; 2) contraction scour (due to accelerated flow caused by a reduction in flow area at a bridge) and; 3) local scour (caused by accelerated flow around piers and abutments). Total scour is the sum of the three components. Equations are available to compute depths for contraction and local scour and a summary of the results of these computations follows.

Contraction scour for all modelled flows ranged from 0.0 to $0.2 \mathrm{ft}$. with the worst-case contraction scour occurring at the 500-year discharge. Abutment scour ranged from 4.2 to $6.4 \mathrm{ft}$. The worst-case abutment scour also occurred at the 500-year discharge. Additional information on scour depths and depths to armoring are included in the section titled "Scour Results". Scoured-streambed elevations, based on the calculated scour depths, are presented in tables 1 and 2. A cross-section of the scour computed at the bridge is presented in figure 8. Scour depths were calculated assuming an infinite depth of erosive material and a homogeneous particle-size distribution.

It is generally accepted that the Froehlich equation (abutment scour) gives "excessively conservative estimates of scour depths" (Richardson and others, 1993, p. 47). Usually, computed scour depths are evaluated in combination with other information including (but not limited to) historical performance during flood events, the geomorphic stability assessment, existing scour protection measures, and the results of the hydraulic analyses. Therefore, scour depths adopted by VTAOT may differ from the computed values documented herein. 


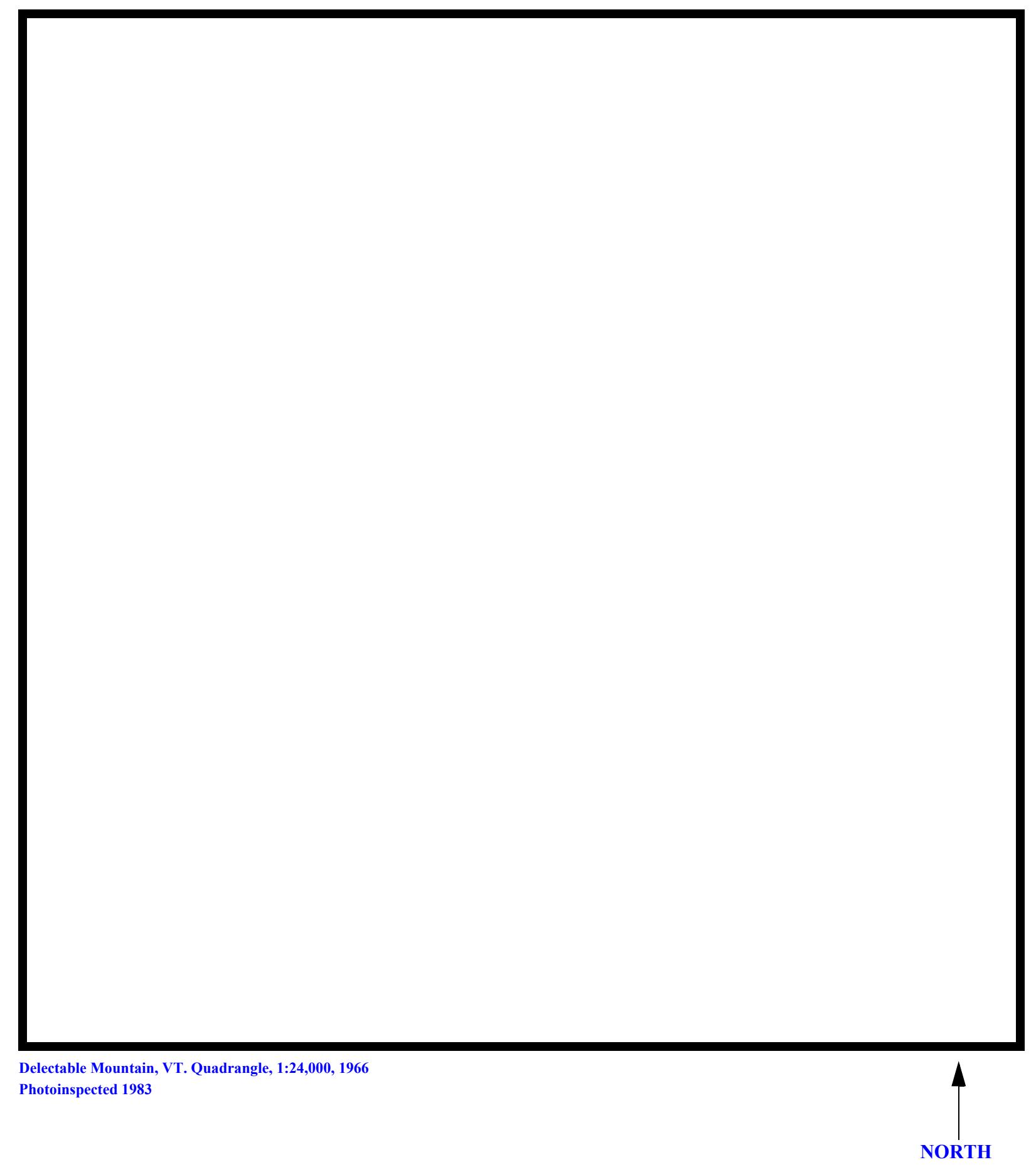

Figure 1. Location of study area on USGS 1:24,000 scale map. 
Figure 2. Location of study area on Vermont Agency of Transportation town highway map. 

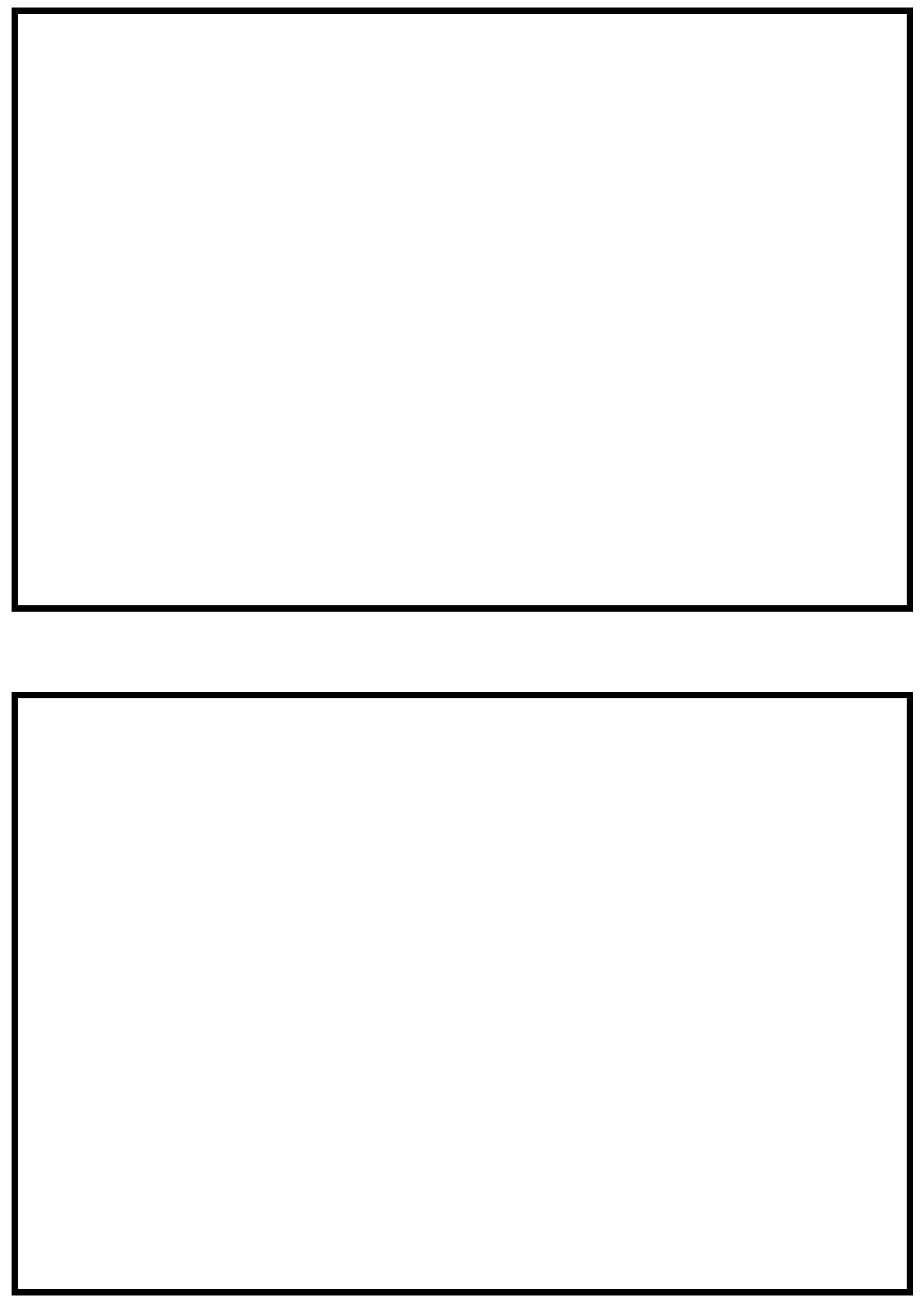

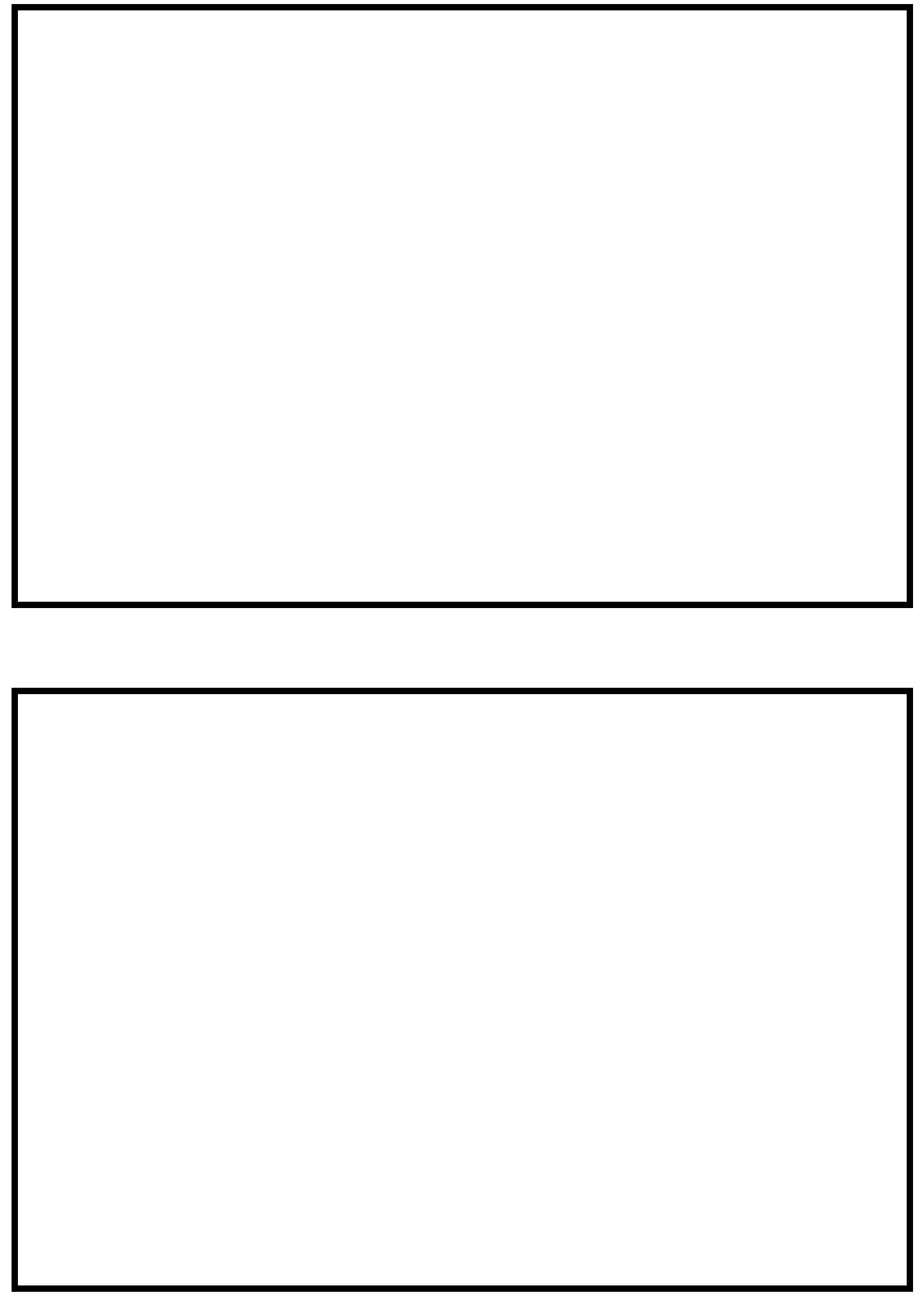


\section{LEVEL II SUMMARY}

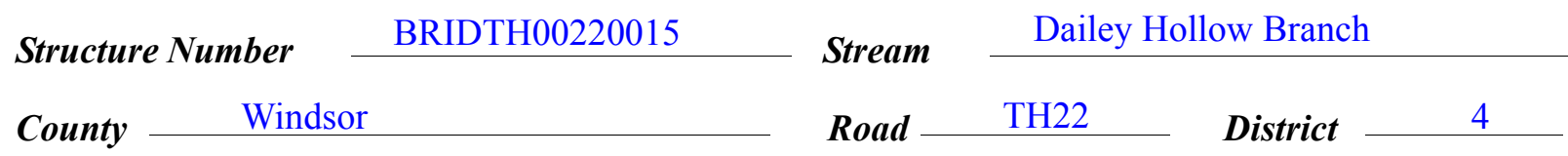

\section{Description of Bridge}

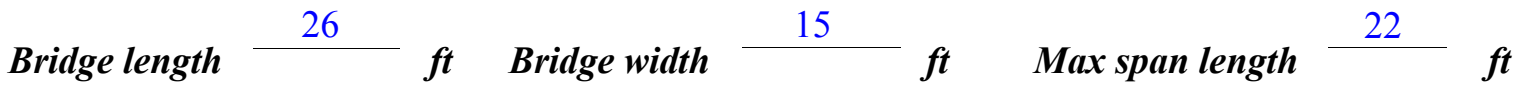
Alignment of bridge to road (on curve or straight)

Abutment type vertical and concrete

Stone fill on abutment?

$$
\text { yes, left }
$$

\section{Embankment type}

$$
\text { sloping }
$$

$11 / 1-2 / 94$ nasmintina sf atan fill Drto of insnortinn
Type-2, in slumped condition at the upstream left wingwall, eroded condition along the left bank upstream. Type-1, in eroded condition at the left abutment.

Abutments are concrete and the left abutment is noted as having an exposed footing with approximately 1 foot of scour.

$-\cdots$

Y

40

Is bridge skewed to flood flow according to Bridg' survey?

Angle

e is located on a moderate bend in the channel. The left bank and abutment are impacted by flood flows.

\begin{tabular}{|c|c|c|c|}
\hline & $\begin{array}{c}\text { Date of incnortion } \\
11 / 1-2 / 94 \\
\end{array}$ & $\begin{array}{l}\text { Percent of shmunal } \\
\text { blocked inortzontatly }\end{array}$ & $\begin{array}{l}\text { Percent of a nerticatty } \\
\text { blocked vertical }\end{array}$ \\
\hline evel I & $11 / 1-2 / 94$ & - & - \\
\hline I I & Moderate & & \\
\hline
\end{tabular}

Debris accumulation on bridge at time of Level I or Level II site visit:

\section{Potential for debris}

The bridge is located on a channel bend and a point bar exists on the right side of the bridge near Doscriho anv, fonturos noar ar at tho hridoo that mav, affort flow, (includo ahsorvation dato) the downstream face. November 1 and 2, 1994. 


\section{Description of the Geomorphic Setting}

General topography The bridge is in a moderate relief valley with narrow flood plains.

Geomorphic conditions at bridge site: downstream (DS), upstream (US)

Date of inspection $\quad 11 / 1-2 / 94$

DS left: $\quad$ narrow flood plain to valley wall

DS right: $\quad$ steep valley wall

US left: $\quad$ narrow flood plain to valley wall

US right: $\quad$ narrow flood plain to valley wall

\section{Description of the Channel}

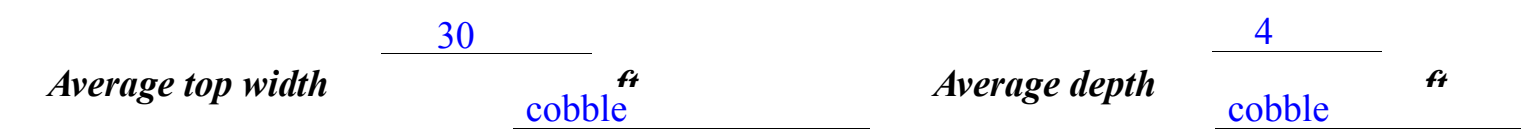

Predominant bed material

Bank material

Narrow channel with

slight sinuosity.

$. \quad .$.

$11 / 1-2 / 94$

Vegetative co 1 forested

DS left: $\quad$ forested

DS right: forested

US left: $\quad$ forested with town highway 22 adjacent to channel

US right: $\quad \underline{\mathrm{N}}$

Do banks appear stable? November 1 and $2,1994--T h e$ upstream left bank is experiencing

heavy fluvial erosion and a cut bank has formed. Downstream left bank is eroded heavily near
date of observatton. the downstream left wingwall. The downstream right bank is reported to have heavy fluvial erosion $40 \mathrm{ft}$. downstream from the bridge.

November 1 and 2,

1994--Point bars upstream and downstream of the bridge may obstruct flow to a small degree. Describe any obstructions in channel and date of observation. 


\section{Hydrology}

Drainage area $\frac{1.73}{\boldsymbol{m i}^{2}}$

Percentage of drainage area in physiographic provinces: (approximate)

Physiographic province/section

New England / Green Mountain
Percent of drainage area 100

Is drainage area considered rural or urban? - Rural Describe any significant urbanization:

None. Area is mostly forested high-elevation headwater drainage.

No

Is there a USGS gage on the stream of interest?

USGS gage description

USGS gage number

Gage drainage area $\quad \mathrm{mi}^{2}$

No

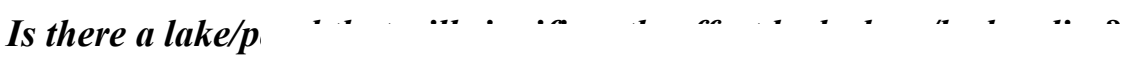

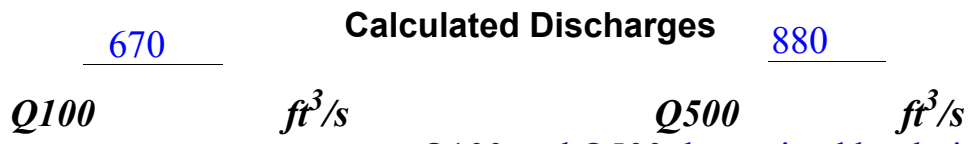

Q100 and Q500 determined by drainage area

relationship_with Bridgewater bridge 30 [(1.7/7.5)to the 0.7 power]. The drainage area of bridge 30 is 7.5 square miles. The 100 -year discharge at bridge 30 (1,900 cubic feet per second) was from the VTAOT database (written communication, 5/4/95). The 500-year discharge at bridge 30 (2,500 cubic feet per second) was estimated from applicable empirical methods (Talbot, 1887; Potter, 1957a; Potter, 1957b; Johnson and Laraway, 1971, written communication; Johnson and Tasker, 1974; Federal Highway Administration, 1983). 


\section{Description of the Water-Surface Profile Model (WSPRO) Analysis}

Datum for WSPRO analysis (USGS survey, sea level, VTAOT plans)

USGS survey

Datum tie between USGS survey and VTAOT plans

None

Description of reference marks used to determine USGS datum. $\quad$ RM1 is a chiseled " $X$ "

at the upstream left bridge seat (elev. 499.66 feet, arbitrary survey datum). RM2 is a chiseled

"X" on the downstream end of the right abutment (elev. 500.60 feet, arbitrary survey datum).

\section{Cross-Sections Used in WSPRO Analysis}

\begin{tabular}{|c|c|c|c|}
\hline${ }^{1}$ Cross-section & $\begin{array}{c}\text { Section } \\
\text { Reference } \\
\text { Distance } \\
\text { (SRD) in feet }\end{array}$ & $\begin{array}{c}{ }^{2} \text { Cross-section } \\
\text { development }\end{array}$ & Comments \\
\hline EXITX & -33 & 1 & Exit section \\
\hline FULLV & 0 & 2 & $\begin{array}{l}\text { Downstream Full-valley } \\
\text { section (Templated from } \\
\text { EXITX) }\end{array}$ \\
\hline BRIDG & 0 & 1 & Bridge section \\
\hline RDWAY & 7 & 1 & Road Grade section \\
\hline APPRO & 45 & 1 & Approach section \\
\hline
\end{tabular}

${ }^{1}$ For location of cross-sections see plan-view sketch included with Level I field form, Appendix E. For more detail on how cross-sections were developed see WSPRO input file. 


\section{Data and Assumptions Used in WSPRO Model}

Hydraulic analyses of the reach were done by use of the Federal Highway Administration's WSPRO step-backwater computer program (Shearman and others, 1986, and Shearman, 1990). The analyses reported herein reflect conditions existing at the site at the time of the study. Furthermore, in the development of the model it was necessary to assume no accumulation of debris or ice at the site. Results of the hydraulic model are presented in the Bridge Hydraulic Summary, Appendix B, and figure 7.

Channel roughness factors (Manning's " $n$ ") used in the hydraulic model were estimated using field inspections at each cross section following the general guidelines described by Arcement and Schneider (1989). Final adjustments to the values were made during the modelling of the reach. Channel " $n$ " values for the reach ranged from 0.060 to 0.065 , and overbank " $\mathrm{n}$ " values ranged from 0.055 to 0.100 .

Normal depth at the exit section (EXITX) was assumed as the starting water surface. This depth was computed by use of the slope-conveyance method outlined in the user's manual for WSPRO (Shearman, 1990). The slope used was $0.035 \mathrm{ft} / \mathrm{ft}$ which was estimated from the topographic map (U.S. Geological Survey, 1966).

The approach section was surveyed approximately one bridge length upstream of the upstream face as recommended by Shearman and others (1986). This approach also provides a consistent method for determining scour variables.

For the 500-year discharge, WSPRO assumes critical depth at the bridge section. A supercritical model was developed for the 500-year discharge. Analyzing both the supercritical and subcritical profiles, it can be determined that the water surface does pass through critical depth within the bridge opening. Thus, the assumptions of critical depth at the bridge is a satifactory solution. In addition, the 500-year discharge model had a froude number of 1.00 at the exit section. It was determined that normal depth was equal to critical depth and thus the critical water surface was allowed. 


\section{Bridge Hydraulics Summary}

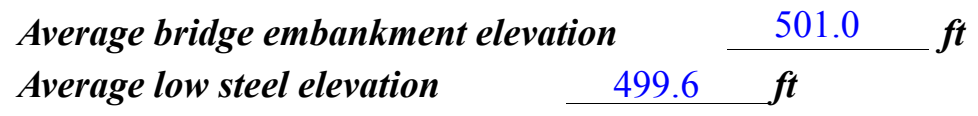

100-year discharge $\quad 670 \quad \mathrm{ft}^{3} / \mathrm{s}$

Water-surface elevation in bridge opening $\quad 496.4 \quad f t$

Road overtopping? ___ N Discharge over road __ _ _ _. s

Area of flow in bridge opening $\quad$\begin{tabular}{l}
$69.2 \quad \boldsymbol{f t}^{2}$ \\
\hline
\end{tabular}

$\begin{array}{llll}\text { Average velocity in bridge opening } \quad 9.7 & f t / s\end{array}$

Maximum WSPRO tube velocity at bridge $11.8 \mathrm{ft} / \mathrm{s}$

Water-surface elevation at Approach section with bridge

498.7

Water-surface elevation at Approach section without bridge

Amount of backwater caused by bridge

$$
0.6 \quad \dot{t}
$$

500-year discharge $\quad 880 \quad \mathrm{ft}^{3} / \mathrm{s}$

Water-surface elevation in bridge opening

$496.9 f t$

Road overtopping? ___ N Discharge over road $--, / s$

Area of flow in bridge opening $\quad 79.7 \quad \mathrm{ft}^{2}$

Average velocity in bridge opening $\quad 11.1 \mathrm{ft} / \mathrm{s}$

Maximum WSPRO tube velocity at bridge 13.7_'s

Water-surface elevation at Approach section with bridge

499.8

Water-surface elevation at Approach section without bridge

Amount of backwater caused by bridge 1.2 .

Incipient overtopping discharge ___ -- $\mathrm{ft}^{3} / \mathrm{s}$

Water-surface elevation in bridge opening $\quad--\quad$ it

Area of flow in bridge opening -- $\mathrm{ft}^{2}$

Average velocity in bridge opening $\quad--\quad f t / s$

Maximum WSPRO tube velocity at bridge _-- $f t / s$

Water-surface elevation at Approach section with bridge

Water-surface elevation at Approach section without bridge

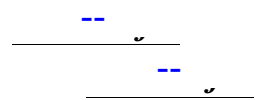
Amount of backwater caused by bridge _ - - it 


\section{Scour Analysis Summary}

\section{Special Conditions or Assumptions Made in Scour Analysis}

Scour depths were computed using the general guidelines described in Hydraulic Engineering Circular 18 (Richardson and others, 1993). Scour depths were calculated assuming an infinite depth of erosive material and a homogeneous particle-size distribution. The results of the scour analysis are presented in tables 1 and 2 and a graph of the scour depths is presented in figure 8.

Contraction scour was computed by use of the clear-water contraction scour equation (Richardson and others, 1993, p. 35, equation 18). For contraction scour computations, the average depth in the contracted section (AREA/TOPWIDTH) is subtracted from the depth of flow computed by the scour equation (Y2) to determine the actual amount of scour. Streambed armoring depths computed suggest that contraction scour will not be limited by armoring.

Abutment scour was computed by use of the Froehlich equation (Richardson and others, 1993, p. 49, equation 24). Variables for the Froehlich equation include the Froude number of the flow approaching the embankments, the length of the embankment blocking flow, and the depth of flow approaching the embankment less any roadway overtopping. 


\section{Scour Results}

\section{0-yr discharge 500-yr discharge}

Contraction scour:

(Scour depths in feet)

Main channel

Live-bed scour

Clear-water scour

Depth to armoring

Left overbank

Right overbank

Local scour:

Abutment scour

Left abutment

6.1

6.4

4.2

$5.2-$

Right abutment

Pier scour

Pier 1

Pier 2

Pier 3

\section{Abutments:}

Left abutment

Right abutment

Piers:

Pier 1

Pier 2

Incipient overtopping discharge 


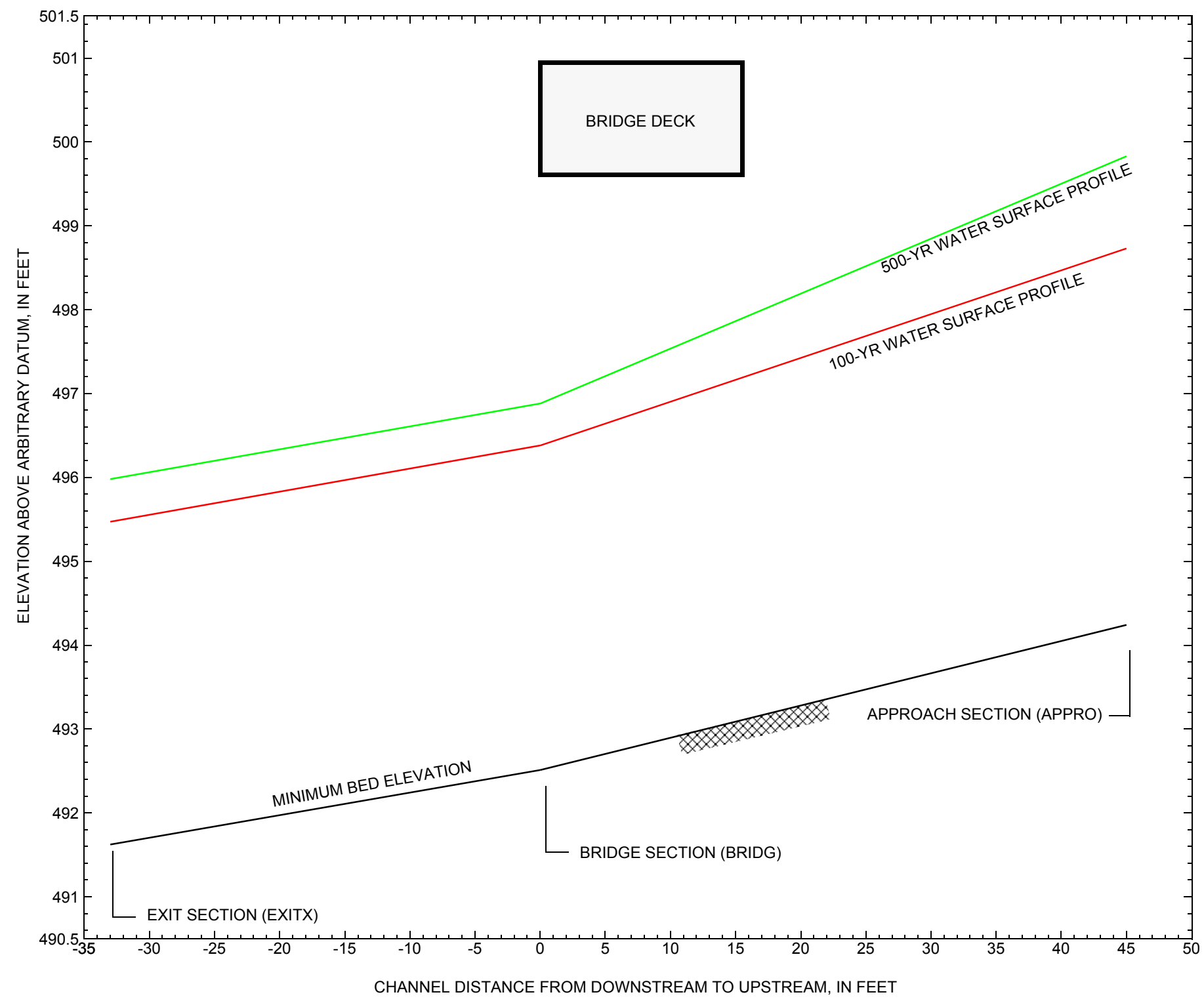

Figure 7. Water-surface profiles for the 100- and 500-yr discharges at structure BRIDTH00220015 on town highway 22, crossing Dailey Hollow Branch, Bridgewater, Vermont. 


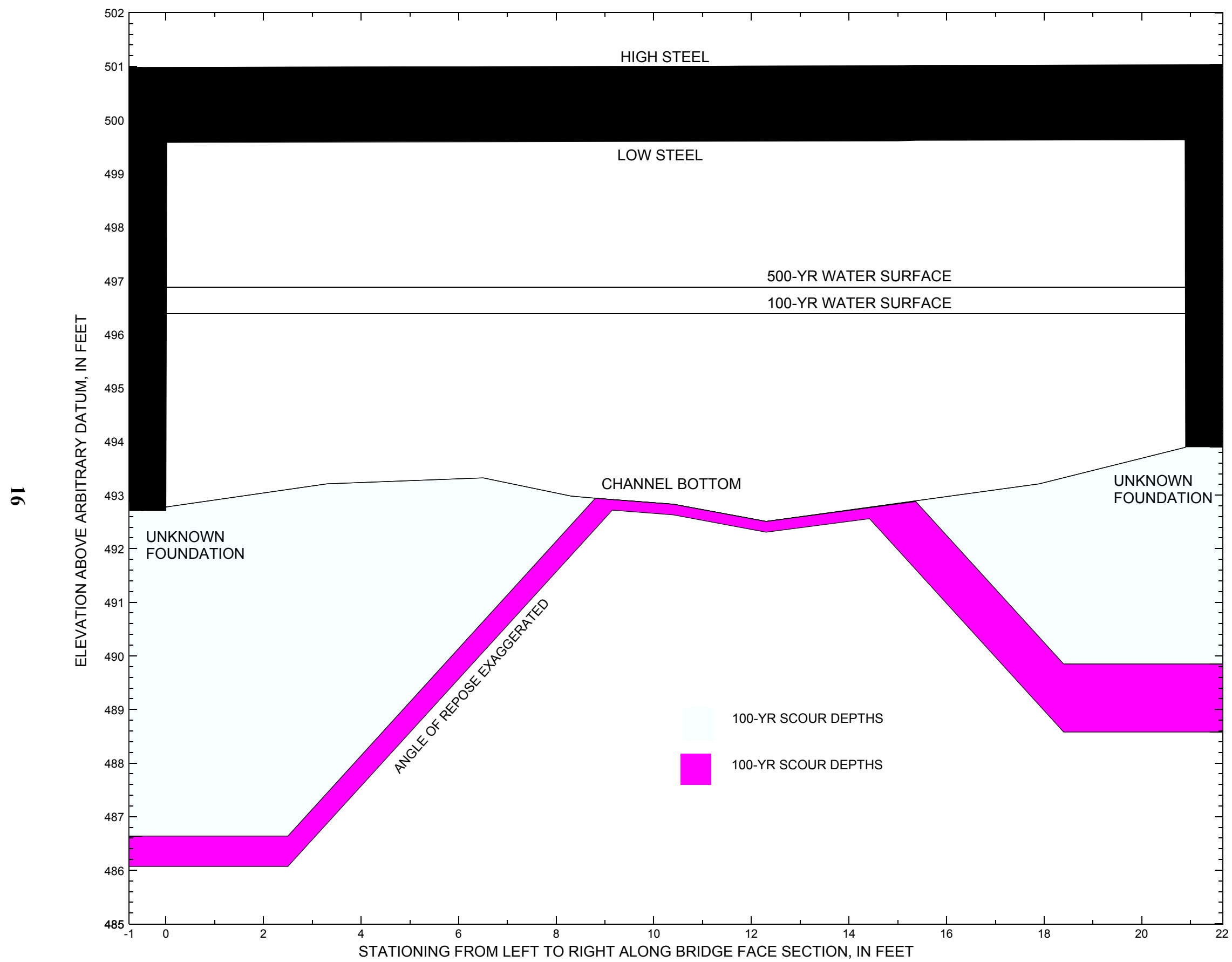

Figure 8. Scour elevations for the 100-yr and 500-yr discharges at structure BRIDTH00220015 on town highway 22, crossing Dailey Hollow Branch, Bridgewater, Vermont. 
Table 1. Remaining footing/pile depth at abutments for the 100-year discharge at structure BRIDTH00220015 on Town Highway 22, crossing Dailey Hollow Branch, Bridgewater, Vermont.

[VTAOT, Vermont Agency of Transportation; --,no data]

\begin{tabular}{|c|c|c|c|c|c|c|c|c|c|c|c|}
\hline Description & Station $^{1}$ & $\begin{array}{l}\text { VTAOT } \\
\text { minimum } \\
\text { low-chord } \\
\text { elevation } \\
\text { (feet) }\end{array}$ & $\begin{array}{l}\text { Surveyed } \\
\text { minimum } \\
\text { low-chord } \\
\text { elevation } \\
\quad \text { (feet) }\end{array}$ & $\begin{array}{l}\text { Bottom of } \\
\text { footing } \\
\text { elevation } \\
\text { (feet) }\end{array}$ & $\begin{array}{c}\text { Channel } \\
\text { elevation at } \\
\text { abutment/ } \\
\text { pier }^{2} \\
\text { (feet) }\end{array}$ & $\begin{array}{l}\text { Contraction } \\
\text { scour depth } \\
\text { (feet) }\end{array}$ & $\begin{array}{l}\text { Abutment } \\
\text { scour } \\
\text { depth } \\
\text { (feet) }\end{array}$ & $\begin{array}{l}\text { Pier } \\
\text { scour } \\
\text { depth } \\
\text { (feet) }\end{array}$ & $\begin{array}{l}\text { Depth of } \\
\text { total scour } \\
\text { (feet) }\end{array}$ & $\begin{array}{c}\text { Elevation of } \\
\text { scour }^{2} \\
\text { (feet) }\end{array}$ & $\begin{array}{c}\text { Remaining } \\
\text { footing/pile } \\
\text { depth } \\
\text { (feet) }\end{array}$ \\
\hline \multicolumn{12}{|c|}{100 -yr. discharge is 670 cubic-feet per second } \\
\hline Left abutment & 0.0 & -- & 499.6 & -- & 492.7 & 0.0 & 6.1 & -- & 6.1 & 486.6 & -- \\
\hline Right abutment & 20.9 & -- & 499.6 & -- & 494.0 & 0.0 & 4.2 & -- & 4.2 & 489.8 & -- \\
\hline
\end{tabular}

1. Measured along the face of the most constricting side of the bridge.

2. Arbitrary datum for this study.

Table 2. Remaining footing/pile depth at abutments for the 500-year discharge at structure BRIDTH00220015 on Town Highway 22, crossing Dailey Hollow Branch, Bridgewater, Vermont.

[VTAOT, Vermont Agency of Transportation; --, no data]

\begin{tabular}{|c|c|c|c|c|c|c|c|c|c|c|c|}
\hline Description & Station $^{1}$ & $\begin{array}{l}\text { VTAOT } \\
\text { minimum } \\
\text { low-chord } \\
\text { elevation } \\
\text { (feet) }\end{array}$ & $\begin{array}{l}\text { Surveyed } \\
\text { minimum } \\
\text { low-chord } \\
\text { elevation } \\
\quad \text { (feet) }\end{array}$ & $\begin{array}{l}\text { Bottom of } \\
\text { footing } \\
\text { elevation } \\
\text { (feet) }\end{array}$ & $\begin{array}{c}\text { Channel } \\
\text { elevation at } \\
\text { abutment/ } \\
\text { pier }^{2} \\
\text { (feet) }\end{array}$ & $\begin{array}{l}\text { Contraction } \\
\text { scour depth } \\
\text { (feet) }\end{array}$ & $\begin{array}{l}\text { Abutment } \\
\text { scour } \\
\text { depth } \\
\text { (feet) }\end{array}$ & $\begin{array}{l}\text { Pier } \\
\text { scour } \\
\text { depth } \\
\text { (feet) }\end{array}$ & $\begin{array}{l}\text { Depth of } \\
\text { total scour } \\
\text { (feet) }\end{array}$ & $\begin{array}{c}\text { Elevation of } \\
\text { scour }^{2} \\
\text { (feet) }\end{array}$ & $\begin{array}{c}\text { Remaining } \\
\text { footing/pile } \\
\text { depth } \\
\text { (feet) }\end{array}$ \\
\hline \multicolumn{12}{|c|}{500 -yr. discharge is 880 cubic-feet per second } \\
\hline Left abutment & 0.0 & -- & 499.6 & -- & 492.7 & 0.2 & 6.4 & -- & 6.6 & 486.1 & -- \\
\hline Right abutment & 20.9 & -- & 499.6 & -- & 494.0 & 0.2 & 5.2 & -- & 5.4 & 488.6 & -- \\
\hline
\end{tabular}

1. Measured along the face of the most constricting side of the bridge.

2. Arbitrary datum for this study. 


\section{SELECTED REFERENCES}

Arcement, G.J., Jr., and Schneider, V.R., 1989, Guide for selecting Manning's roughness coefficients for natural channels and flood plains: U.S. Geological Survey Water-Supply Paper 2339, 38 p.

Barnes, H.H., Jr., 1967, Roughness characteristics of natural channels: U.S. Geological Survey Water-Supply Paper 1849, 213 p.

Brown, S.A. and Clyde, E.S., 1989, Design of riprap revetment: Federal Highway Administration Hydraulic Engineering Circular No. 11, Publication FHWA-IP-89-016, 156 p.

Federal Highway Administration, 1983, Runoff estimates for small watersheds and development of sound design: Federal Highway Administration Report FHWA-RD-77-158

Froehlich, D.C., 1989, Local scour at bridge abutments in Ports, M.A., ed., Hydraulic Engineering--Proceedings of the 1989 National Conference on Hydraulic Engineering: New York, American Society of Civil Engineers, p. 13-18.

Hayes, D.C.,1993, Site selection and collection of bridge-scour data in Delaware, Maryland, and Virginia: U.S. Geological Survey Water-Resources Investigation Report 93-4017, 23 p.

Interagency Advisory Committee on Water Data, 1982, Guidelines for determining flood flow frequency: U.S. Geological Survey, Bulletin 17B of the Hydrology Subcommittee, $190 \mathrm{p}$.

Johnson, C.G. and Tasker, G.D.,1974, Progress report on flood magnitude and frequency of Vermont streams: U.S. Geological Survey Open-File Report 74-130, 37 p.

Lagasse, P.F., Schall, J.D., Johnson, F., Richardson, E.V., Chang, F., 1995, Stream Stability at Highway Structures: Federal Highway Administration Hydraulic Engineering Circular No. 20, Publication FHWA-IP-90-014, 144 p.

Laursen, E.M., 1960, Scour at bridge crossings: Journal of the Hydraulics Division, American Society of Civil Engineers, v. 86, no. HY2, p. 39-53.

Potter, W. D., 1957a, Peak rates of runoff in the Adirondack, White Mountains, and Maine woods area, Bureau of Public Roads

Potter, W. D., 1957b, Peak rates of runoff in the New England Hill and Lowland area, Bureau of Public Roads

Richardson, E.V. and Davis, S.R., 1995, Evaluating scour at bridges: Federal Highway Administration Hydraulic Engineering Circular No. 18, Publication FHWA-IP-90-017, 204 p.

Richardson, E.V., Simons, D.B., and Julien, P.Y., 1990, Highways in the river environment: Federal Highway Administration Publication FHWA-HI-90-016.

Ritter, D.F., 1984, Process Geomorphology: W.C. Brown Co., Debuque, Iowa, 603 p.

Shearman, J.O., 1990, User's manual for WSPRO--a computer model for water surface profile computations: Federal Highway Administration Publication FHWA-IP-89-027, 187 p.

Shearman, J.O., Kirby, W.H., Schneider, V.R., and Flippo, H.N., 1986, Bridge waterways analysis model; research report: Federal Highway Administration Publication FHWA-RD-86-108, 112 .

Talbot, A.N., 1887, The determination of water-way for bridges and culverts.

U.S. Department of Transportation, 1993, Stream stability and scour at highway bridges, Participant Workbook: Federal Highway Administration Publication FHWA HI-91-011.

U.S. Geological Survey, 1966, Plymouth, Vermont 7.5 Minute Series quadrangle map: U.S. Geological Survey Topographic Maps, Photoinspected 1983, Scale 1:24,000. 


\section{APPENDIX A: \\ WSPRO INPUT FILE}




\section{WSPRO INPUT FILE}

SA

$\mathrm{X}$

$\mathrm{BR}$

GR

GR

GR

$\mathrm{N}$

CD

*

$\mathrm{XR}$

GR

GR

GR

AS

GR

GR

GR

GR

$\mathrm{N}$

SA

*

HP 1 APPRO

HP 2 APPRO

HP 1 BRIDG

HP 2 BRIDG

*

HP 1 APPRO

HP 2 APPRO

HP 1 BRIDG

HP 2 BRIDG

*

EX

ER
U.S. GEOLOGICAL SURVEY WSPRO INPUT FILE bridO15.wsp CREATED ON 02-MAY-95 FOR BRIDGE BRIDTH00220015 USING FILE brid015.dca Dailey Hollow Branch, Town Highway 22, Town of Bridgewater

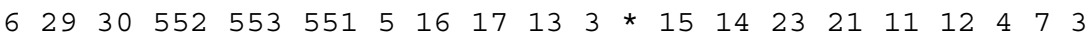

670880

0.0350 .035
$-121.7,499.48$

$-27.1,497.45$

$2.7,492.37$

$16.2,492.01$

$9.7,492.09$

$37.0,505.55$

0.100

$-6.5$

0.065

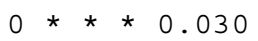

$$
0.0,499.58
$$

$0.1,492.71$

$10.4,492.83$

$20.9,494.01$

$17.9,493.21$

0.06

121.4 * 1505.4

$-86.1,499.10$

$-18.0,496.06$

$4.1,491.62$

$19.2,492.27$

$3.3,493.21$

$6.5,493.32$

$12.3,492.51$

$20.9,499.60$

$15.0,492.83$

$0.0,499.58$
$-6.5,495.11$

$6.3,491.79$

$23.3,496.73$
$-73.5,499.09$
RDWAY $7 \quad 15 \quad 2$

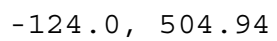




\section{APPENDIX B: \\ WSPRO OUTPUT FILE}




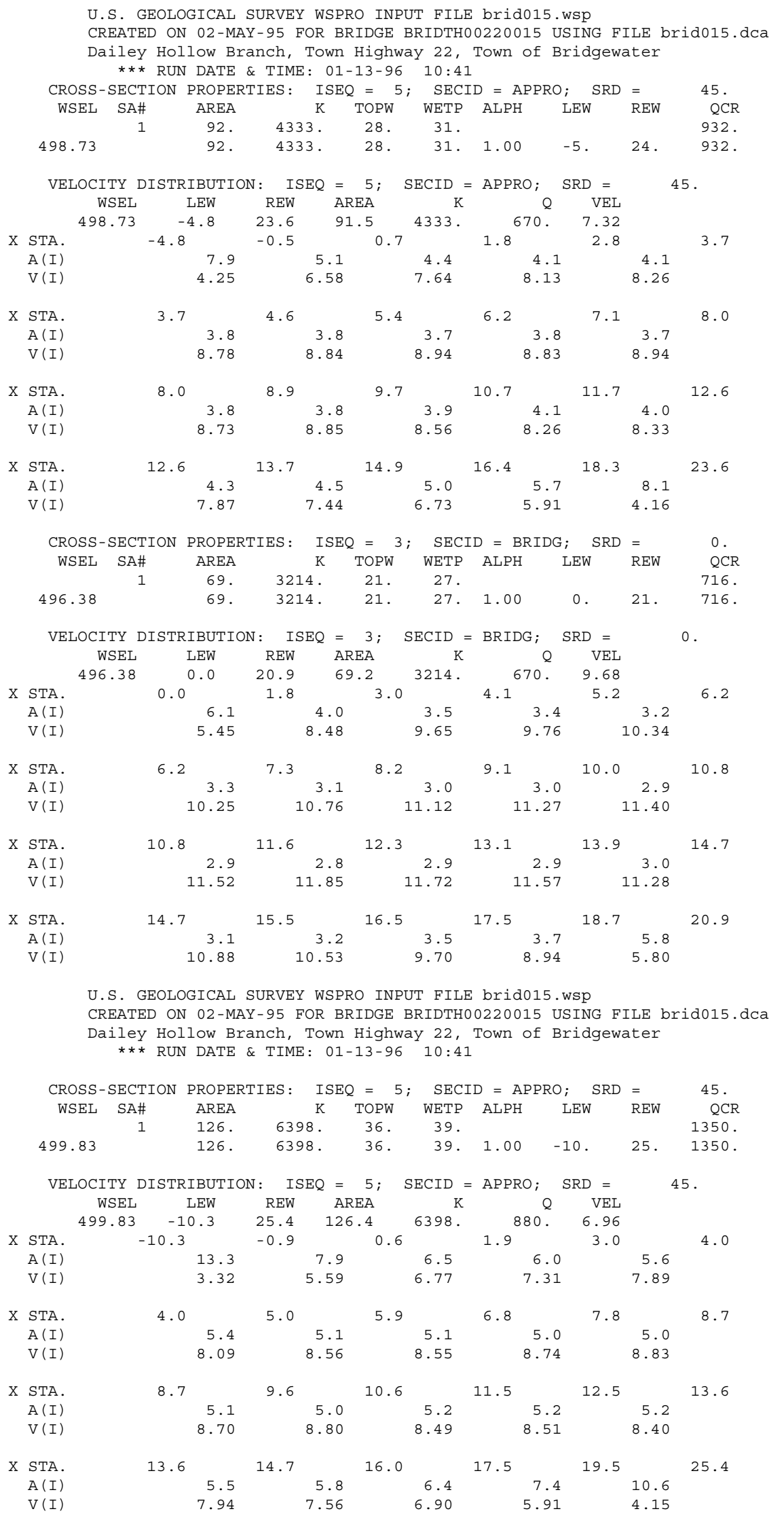


WSPRO OUTPUT FILE (continued)

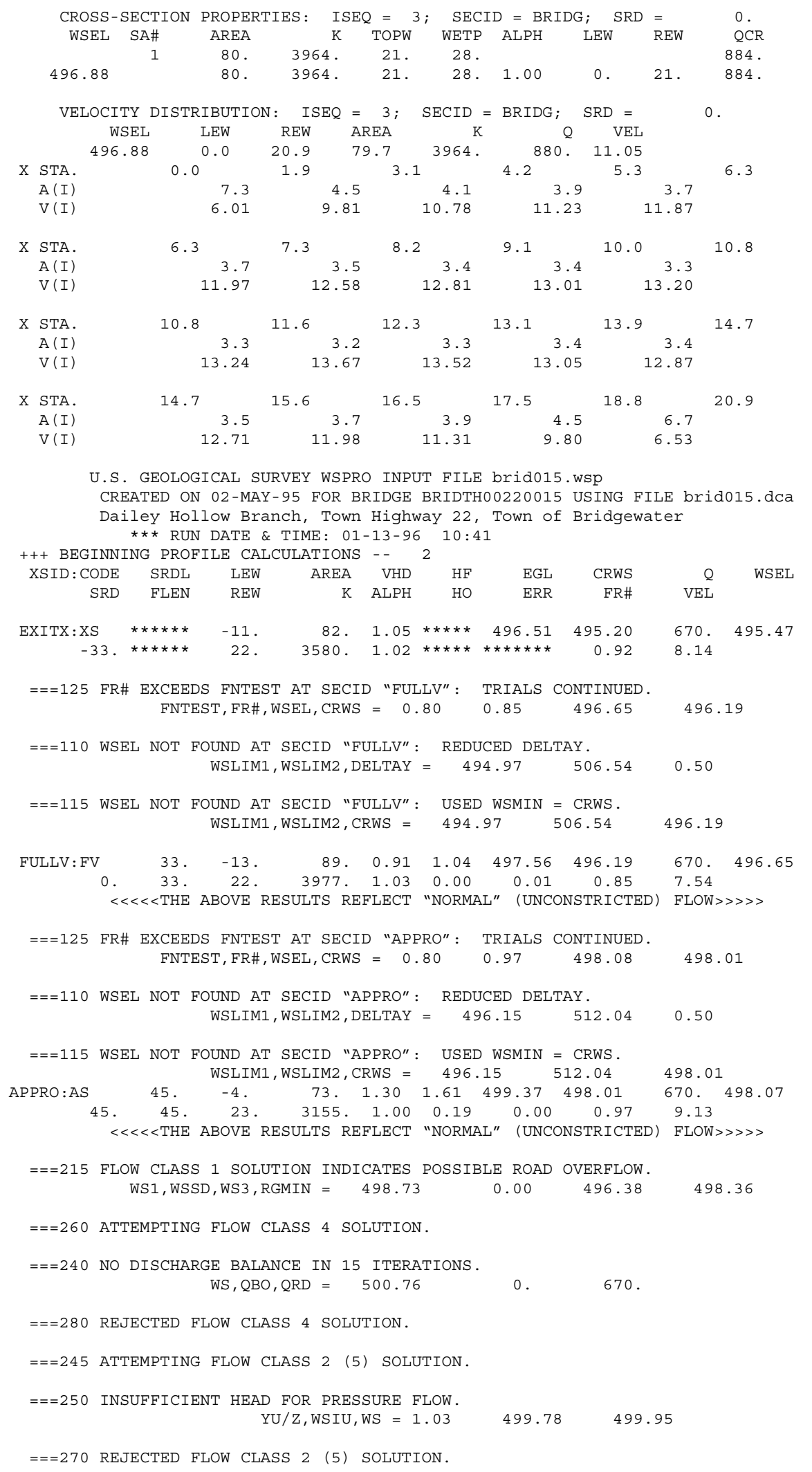

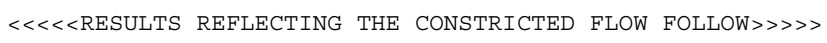


WSPRO OUTPUT FILE (continued)

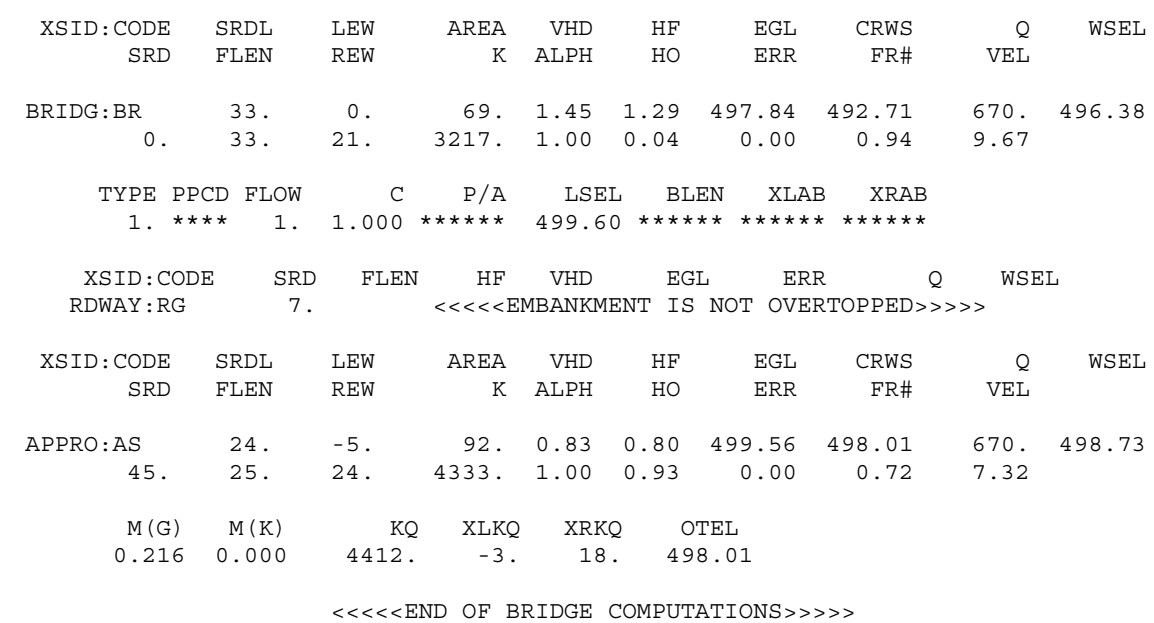

FIRST USER DEFINED TABLE.

\begin{tabular}{|c|c|c|c|c|c|c|c|c|}
\hline XSID : CODE & SRD & LEW & REW & Q & K & AREA & VEL & WSEL \\
\hline EXITX : XS & -33 & -11. & 22 . & 670. & 3580. & 82. & 8.14 & 495.47 \\
\hline FULLV : FV & 0 . & -13. & 22 . & 670. & 3977. & 89 . & 7.54 & 496.65 \\
\hline BRIDG : BR & 0 . & 0 . & 21. & 670. & 3217. & 69. & 9.67 & 496.38 \\
\hline RDWAY : RG & \multicolumn{3}{|c|}{ 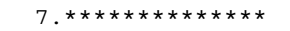 } & \multicolumn{2}{|c|}{ 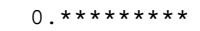 } & 0 . & \multicolumn{2}{|c|}{$2.00 * * * \star * * * *$} \\
\hline APPRO : AS & 45. & -5 & 24 . & 670. & 4333. & 92. & 7.32 & 498.73 \\
\hline XSID : CODE & XLKQ & XRKQ & $\mathrm{K} \varnothing$ & & & & & \\
\hline APPRO : AS & -3 & 18 . & 4412 & & & & & \\
\hline
\end{tabular}

SECOND USER DEFINED TABLE.

$\begin{array}{lcrrrrrrrr}\text { XSID : CODE } & \text { CRWS } & \text { FR\# } & \text { YMIN } & \text { YMAX } & \text { HF } & \text { HO } & \text { VHD } & \text { EGL } & \text { WSEL } \\ \text { EXITX : XS } & 495.20 & 0.92 & 491.62 & 505.55 * * * * * * * * * * * & 1.05 & 496.51 & 495.47 \\ \text { FULLV : FV } & 496.19 & 0.85 & 492.61 & 506.54 & 1.04 & 0.00 & 0.91 & 497.56 & 496.65 \\ \text { BRIDG : BR } & 492.71 & 0.94 & 492.51 & 499.60 & 1.29 & 0.04 & 1.45 & 497.84 & 496.38 \\ \text { RDWAY: RG } & * * * * * * * * * * * * * * & 498.36 & 506.00 * * * * * * * * * * & 0.41 & 500.06 * * * * * * \\ \text { APPRO:AS } & 498.01 & 0.72 & 494.24 & 512.04 & 0.80 & 0.93 & 0.83 & 499.56 & 498.73\end{array}$

U.S. GEOLOGICAL SURVEY WSPRO INPUT FILE brid015.wSp

CREATED ON 02-MAY-95 FOR BRIDGE BRIDTH00220015 USING FILE brid015.dCa

Dailey Hollow Branch, Town Highway 22, Town of Bridgewater

*** RUN DATE \& TIME: 01-13-96 10:41

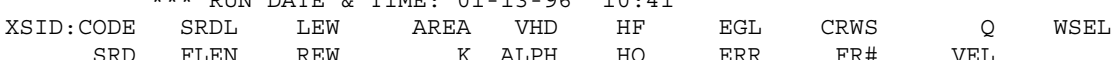

EXITX:XS $* * * * * * \quad-17 . \quad 101 . \quad 1.26 * * * * * \quad 497.25 \quad 495.78 \quad 880.495 .98$

$\begin{array}{lllllll}-33 . * * * * * * & 23 . & 4701 . & 1.07 * * * * * * * * * * * * & 1.00 & 8.71\end{array}$

$==125$ FR\# EXCEEDS FNTEST AT SECID "FULLV": TRIALS CONTINUED.

FNTEST, FR\#, WSEL, CRWS $=0.80 \quad 0.90 \quad 497.21 \quad 496.77$

$==110$ WSEL NOT FOUND AT SECID "FULLV": REDUCED DELTAY.

WSLIM1, WSLIM2, DELTAY $=495.48 \quad 506.54 \quad 0.50$

$===115$ WSEL NOT FOUND AT SECID "FULLV": USED WSMIN = CRWS .

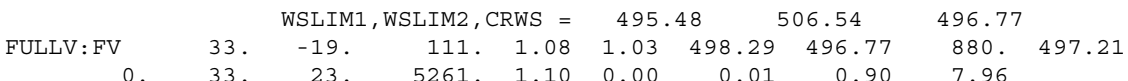

$<<<<$ THE ABOVE RESULTS REFLECT "NORMAL" (UNCONSTRICTED) FLOW $>>>>$

$===125$ FR\# EXCEEDS FNTEST AT SECID "APPRO": TRIALS CONTINUED.

FNTEST, FR\#, WSEL, CRWS $=0.80 \quad 1.00 \quad 498.59 \quad 498.59$

$==110$ WSEL NOT FOUND AT SECID "APPRO": REDUCED DELTAY.

WSLIM1, WSLIM2, DELTAY $=496.71 \quad 512.04 \quad 0.50$

$==115$ WSEL NOT FOUND AT SECID "APPRO": USED WSMIN = CRWS.

APPRO: AS $\quad 45$ WSLIM1, WSLIM2, CRWS $=496.71 \quad 512.04 \quad 498.59$

$\begin{array}{llll}500.16 & 498.59 & 880.498 .59\end{array}$

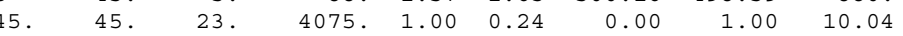

$\ll<<$ THE ABOVE RESULTS REFLECT "NORMAL" (UNCONSTRICTED) FLOW >>>> 


\section{WSPRO OUTPUT FILE (continued)}

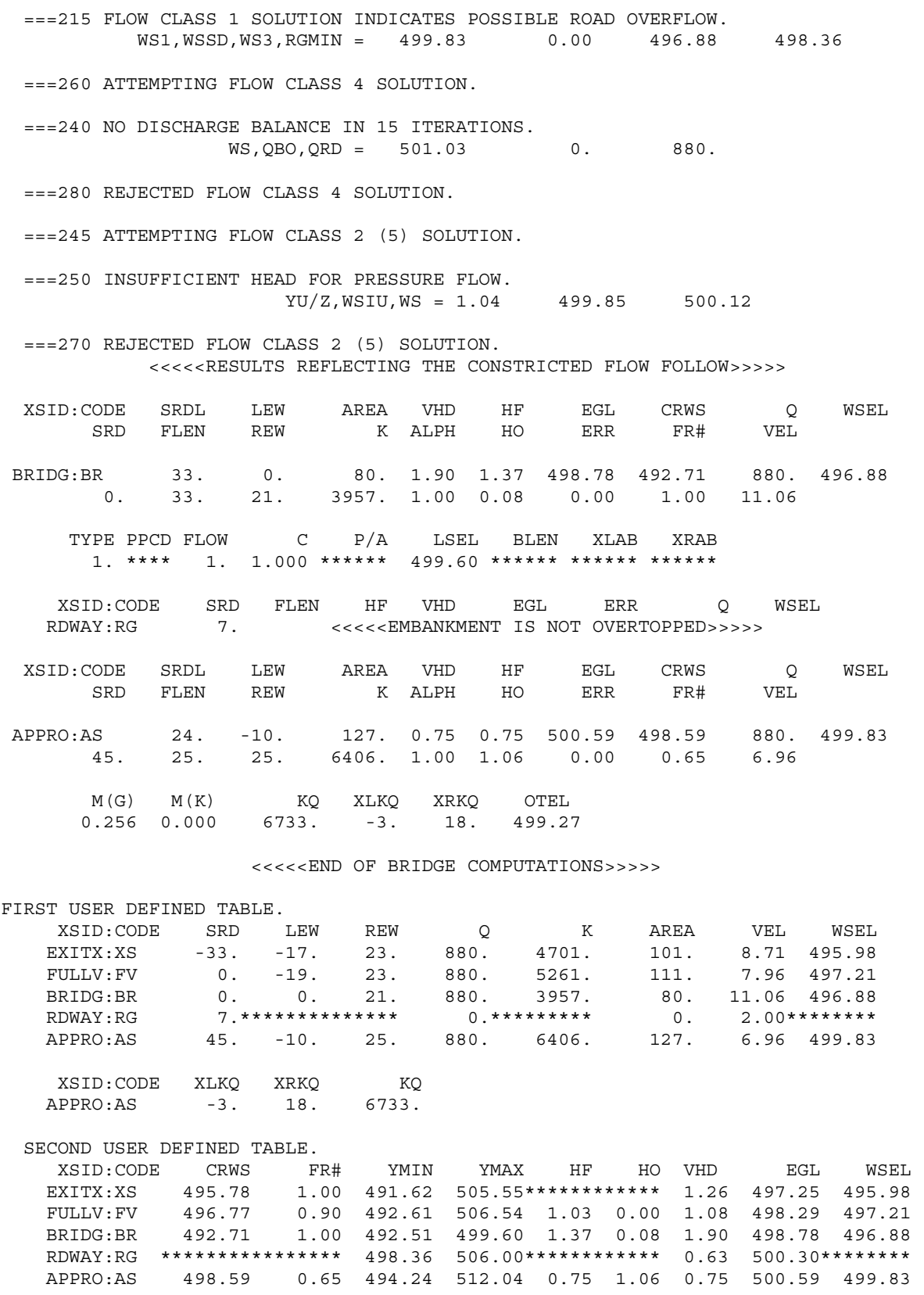




\section{APPENDIX C:}

\section{BED-MATERIAL PARTICAL-SIZE DISTRIBUTION}




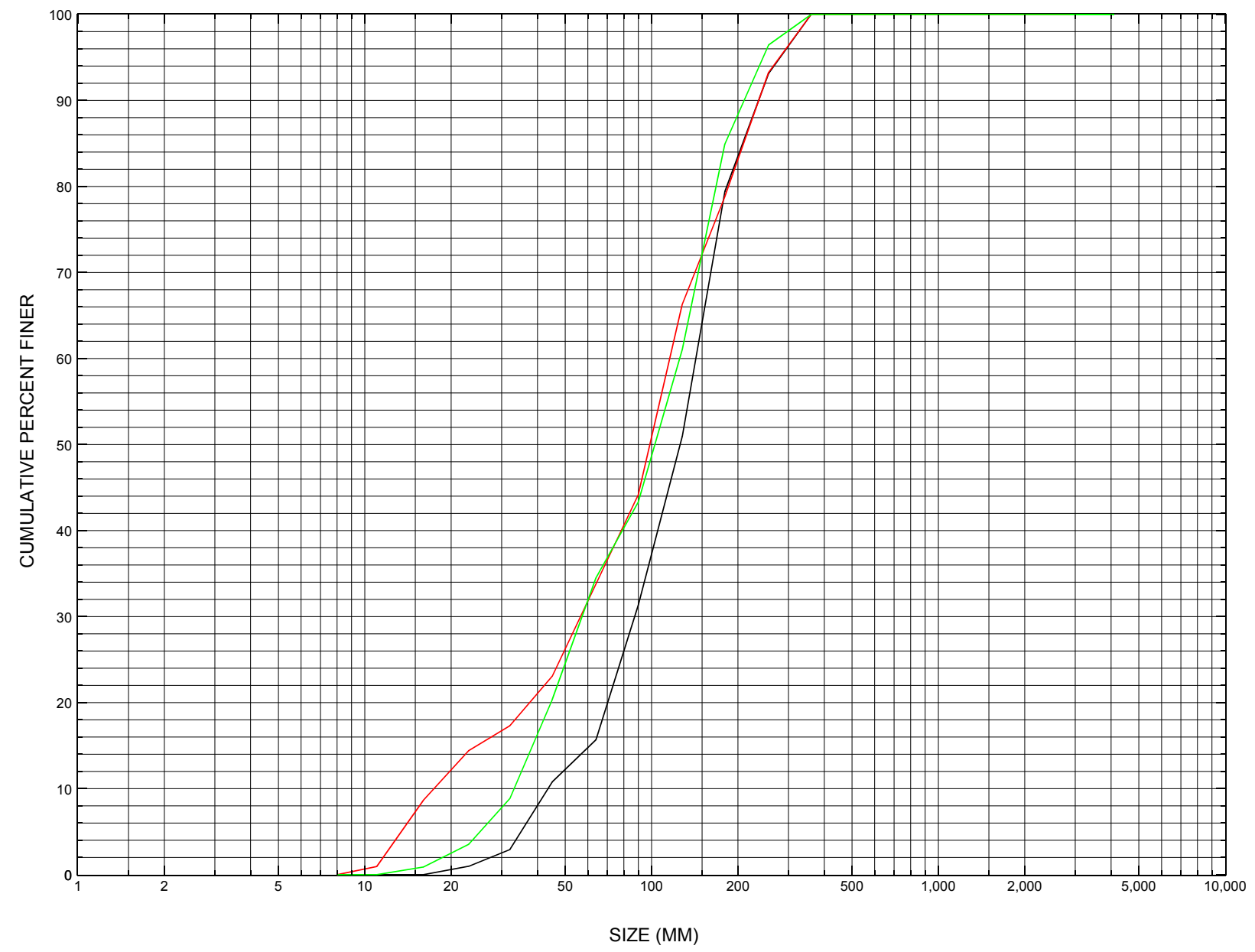

Appendix C. Bed material particle-size distributions for three pebble count transects at the approach cross-section for structure BRIDTH00220015, in Bridgewater, Vermont. 


\section{APPENDIX D: \\ HISTORICAL DATA FORM}




\section{Structure Number BRIDTH00220015}

\section{General Location Descriptive}

Data collected by (First Initial, Full last name) $\mathbf{E}$. BOEHMLER

Date $(M M / D D / Y Y) \_\mathbf{0 8} / \underline{\mathbf{2 4}} / \underline{\mathbf{9 4}}$

Highway District Number (I - 2; nn) 04

Town (FIPS place code; I - 4; nnnnn) $\mathbf{0 8 2 7 5}$

Waterway (I - 6) DAILEY HOLLOW BRANCH

Route Number $\underline{\text { TH022 }}$

Topographic Map Delectable.Mtn

Latitude (I - 16; nnnn.n) $\mathbf{4 3 3 8 4}$
County (FIPS county code; I - 3; nnn)

Mile marker (I - 11; nnn.nnn) $\mathbf{0 0 0 0 0 0}$

Road Name (I - 7): -

Vicinity (I - 9) 0.1 MI JCT TH $21+$ TH 22

Hydrologic Unit Code: $\mathbf{0 1 0 8 0 1 0 6}$

Longitude (i - 17; nnnnn.n) $\mathbf{7 2 4 3 3}$

\section{Select Federal Inventory Codes}

FHWA Structure Number $(I-8) \underline{10140500151405}$

Maintenance responsibility $(I-21 ; n n) \quad \mathbf{0 3} \quad$ Maximum span length $(I-48 ; n n n n) \underline{\mathbf{0 0 2 2}}$

Year built (I - 27; YYYY) 1974

Structure length (I - 49; nnnnnn) $\underline{\mathbf{0 0 0 0 2 6}}$

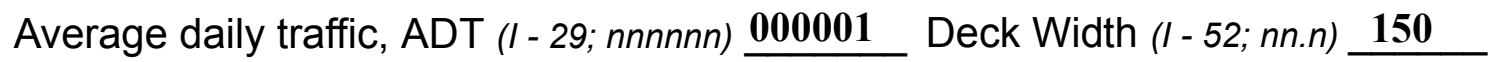

Year of ADT (I - 30; YY) $\underline{\mathbf{9 1}}$

Channel \& Protection $(I-61 ; n) \underline{\mathbf{6}}$

Opening skew to Roadway $(I-34 ; n n) \quad \mathbf{0 0}$

Waterway adequacy $(I-71 ; n)$

Operational status $(I-41 ; X)$ A

Underwater Inspection Frequency $(I-92 B ; X Y Y) \_\mathbf{N}$

Structure type (I- 43; nnn) $\mathbf{3 0 2}$

Year Reconstructed (I - 106) $\mathbf{0 0 0 0}$

Approach span structure type (I - 44; nnn) $\mathbf{0 0 0}$

Clear span (nnn.n ft) _

Number of spans (I - 45; nnn) $\mathbf{0 0 1}$

Vertical clearance from streambed (nnn.n ft) $\underline{\mathbf{0 0 6 . 0}}$

Number of approach spans (I - 46; nnnn) $\mathbf{0 0 0 0}$ Waterway of full opening $\left(n n n . n \mathrm{ft}^{2}\right)$

Comments:

Structural inspection report of 10/18/93 indicates a steel I-beam and timber deck type bridge with a gravel road approach surface. The abutments and wingwalls are reported in like new condition. The downstream end of the left abutment is exposed up to 1 foot above the tip of the streambed. The report indicates no undermining or settlement is apparent. Channel scour is localized at the downstream end of the left abutment. No embankment erosion or drift/vegetation buildup near the bridge. The channel was noted as making a moderate bend into bridge. Stone fill is reported as natural stone in fair condition. The report recommended additional riprap for along the left abutment. 


\section{Bridge Hydrologic Data}

Is there hydrologic data available? $\underline{\mathbf{N}}$ if No, type ctrl-n $h \quad$ VTAOT Drainage area $\left(m i^{2}\right)$ : -

Terrain character:

Stream character \& type: -

Streambed material: Coarse gravel and a few boulders

Discharge Data (cfs): $\quad \mathrm{Q}_{2.33}-$

$$
\mathrm{Q}_{50}
$$

$\mathrm{Q}_{10}-$

$$
Q_{25} \ldots
$$

Record flood date (MM /DD/YY): - $/$ - $/$ -

Water surface elevation $(f t):-$

Estimated Discharge (cfs): Velocity at $\mathrm{Q}-$ $(\mathrm{ft} / \mathrm{s}):$

Ice conditions (Heavy, Moderate, Light) : -

Debris (Heavy, Moderate, Light):

The stage increases to maximum highwater elevation (Rapidly, Not rapidly):

The stream response is (Flashy, Not flashy):

Describe any significant site conditions upstream or downstream that may influence the stream's stage: -

Watershed storage area (in percent): ${ }_{-} \quad \%$

The watershed storage area is: - _ (1-mainly at the headwaters; 2- uniformly distributed; 3-immediatly upstream oi the site)

Water Surface Elevation Estimates for Existing Structure:

\begin{tabular}{|l|l|l|l|l|l|}
\hline Peak discharge frequency & $Q_{2.33}$ & $Q_{10}$ & $Q_{25}$ & $Q_{50}$ & $Q_{100}$ \\
Water surface elevation (ft)) & - & - & - & - & - \\
Velocity (ft/sec) & - & - & - & - & - \\
\hline
\end{tabular}

Long term stream bed changes: -

Is the roadway overtopped below the $\mathrm{Q}_{100}$ ? (Yes, No, Unknown): $\mathbf{U} \quad$ Frequency: Relief Elevation $(f t)$ : Discharge over roadway at $Q_{100}\left(f^{3} / \mathrm{sec}\right)$ :

Are there other structures nearby? (Yes, No, Unknown): Upstream distance (miles): Town: If No or Unknown, type ctrl-n os Highway No. : Structure No. : Year Built:

Clear span (ft): Clear Height (ft): Full Waterway $\left(f^{2}\right)$ : 
Downstream distance (miles): Town: Year Built:

Highway No. : Structure No. : Structure Type:

Clear span $(f t):$ Clear Height $(f t)$ : Full Waterway $\left(f^{2}\right):$

Comments:

\section{USGS Watershed Data}

Watershed Hydrographic Data

Drainage area $(D A)$

Watershed storage (ST) $\mathrm{mi}^{2}$ Lake and pond area $\mathrm{mi}^{2}$

Bridge site elevation $1560 \quad \mathrm{ft}$ $\%$

Main channel length 2.314 mi $10 \%$ channel length elevation 1600 $\mathrm{ft} \quad 85 \%$ channel length elevation $\mathrm{ft}$

Main channel slope (S) 368.77 $\mathrm{ft} / \mathrm{mi}$

Watershed Precipitation Data

Average site precipitation in

Average headwater precipitation in

Maximum 2yr-24hr precipitation event $(124,2)$ in

Average seasonal snowfall (Sn) $\mathrm{ft}$ 


\section{Bridge Plan Data}

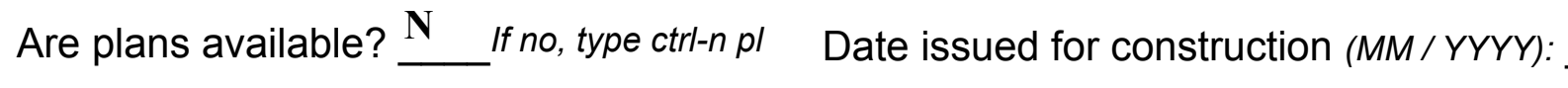

Project Number

Minimum channel bed elevation:

Low superstructure elevation: USLAB DSLAB USRAB DSRAB Benchmark location description:

NO BENCHMARK INFORMATION

Reference Point (MSL, Arbitrary, Other): Datum (NAD27, NAD83, Other):

Foundation Type: 4

If 1 : Footing Thickness

If 2: Pile Type:

If 3: Footing bottom elevation:

Is boring information available? $\mathbf{N}$

Foundation Material Type: $\mathbf{3}$

(1-Spreadfooting; 2-Pile; 3- Gravity; 4-Unknown)

Footing bottom elevation: -

Briefly describe material at foundation bottom elevation or around piles:

NO FOUNDATION MATERIAL INFORMATION

Comments:

NO PLANS. 


\section{Cross-sectional Data}

Is cross-sectional data available? $\mathbf{N}$ If no, type ctrl-n xs

Source (FEMA, VTAOT, Other)? -

Comments: NO CROSS SECTION INFORMATION

\begin{tabular}{|l|l|l|l|l|l|l|l|l|l|l|l|}
\hline Station & - & - & - & - & - & - & - & - & - & - & - \\
\hline Feature & - & - & - & - & - & - & - & - & - & - & - \\
\hline $\begin{array}{l}\text { Low cord } \\
\text { elevation }\end{array}$ & - & - & - & - & - & - & - & - & - & - & - \\
\hline $\begin{array}{l}\text { Bed } \\
\text { elevation }\end{array}$ & - & - & - & - & - & - & - & - & - & - & - \\
\hline $\begin{array}{l}\text { Low cord to } \\
\text { bed length }\end{array}$ & - & - & - & - & - & - & - & - & - & - & - \\
\hline Station & - & - & - & - & - & - & - & - & - & - & - \\
\hline Feature & - & - & - & - & - & - & - & - & - & - & - \\
\hline $\begin{array}{l}\text { Low cord } \\
\text { elevation }\end{array}$ & - & - & - & - & - & - & - & - & - & - & - \\
\hline $\begin{array}{l}\text { Bed } \\
\text { elevation }\end{array}$ & - & - & - & - & - & - & - & - & - & - & - \\
\hline $\begin{array}{l}\text { Low cord to } \\
\text { bed length }\end{array}$ & - & - & - & - & - & - & - & - & - & - & - \\
\hline
\end{tabular}

Source (FEMA, VTAOT, Other)?

Comments: NO CROSS SECTION INFORMATION

\begin{tabular}{|l|l|l|l|l|l|l|l|l|l|l|l|}
\hline Station & - & - & - & - & - & - & - & - & - & - & - \\
\hline Feature & - & - & - & - & - & - & - & - & - & - & - \\
\hline $\begin{array}{l}\text { Low cord } \\
\text { elevation }\end{array}$ & - & - & - & - & - & - & - & - & - & - & - \\
\hline $\begin{array}{l}\text { Bed } \\
\text { elevation }\end{array}$ & - & - & - & - & - & - & - & - & - & - & - \\
\hline $\begin{array}{l}\text { Low cord to } \\
\text { bed length }\end{array}$ & - & - & - & - & - & - & - & - & - & - & - \\
\hline Station & - & - & - & - & - & - & - & - & - & - & - \\
\hline Feature & - & - & - & - & - & - & - & - & - & - & - \\
\hline $\begin{array}{l}\text { Low cord } \\
\text { elevation }\end{array}$ & - & - & - & - & - & - & - & - & - & - & - \\
\hline $\begin{array}{l}\text { Bed } \\
\text { levation }\end{array}$ & - & - & - & - & - & - & - & - & - & - & - \\
\hline $\begin{array}{l}\text { Low cord to } \\
\text { bed length }\end{array}$ & - & - & - & - & - & - & - & - & - & - & - \\
\hline
\end{tabular}




\section{APPENDIX E: \\ LEVEL I DATA FORM}


U. S. Geological Survey

Bridge Field Data Collection and Processing Form

Qa/Qc Check by: DLS

Date: $\mathbf{0 2 / 0 2 / 9 5}$

\section{Structure Number}

BRIDTH00220015

\section{A. General Location Descriptive}

1. Data collected by (First Initial, Full last name) $\underline{\mathbf{J}}$. AYOTTE

2. Highway District Number 04

County 027

Waterway (l - 6) DAILEY HOLLOW BRANCH

Route Number $\mathbf{T H 0 2 2}$

3. Descriptive comments:

The bridge is 0.1 miles from the junction of TH021 and TH022.
Mile marker 000000

Town BRIDGEWATER

Road Name -

Hydrologic Unit Code: $\mathbf{0 1 0 8 0 1 0 6}$

Date $(M M / D D / Y Y) \underline{11} / \underline{01} / \underline{1994}$

\section{B. Bridge Deck Observations}
4. Surface cover... LBUS 6
RBUS 6
LBDS 6
RBDS 6
Overall 6

(2b us,ds,lb,rb: 1- Urban; 2- Suburban; 3- Row crops; 4- Pasture; 5- Shrub- and brushland; 6- Forest; 7- Wetland)
5. Ambient water surface...US $\underline{2}$
UB 2
DS $\underline{2}$
(1- pool; 2- riffle)

6. Bridge structure type 1 (1- single span; 2- multiple span; 3- single arch; 4- multiple arch; 5-cylindrical culvert; 6- box culvert; or 7- other)
7. Bridge length 26
(feet)
Span length $\underline{\mathbf{2 2}}$
(feet)
Bridge width 15 (feet)

\section{Road approach to bridge:}
8. LB 1 RB 1
( 0 even, 1- lower, 2- higher)
9. LB 2
RB $\underline{2}$
(1-Paved, 2- Not paved)

10. Embankment slope (run / rise in feet / foot)

US left

0.0:1

US right

0.0:1

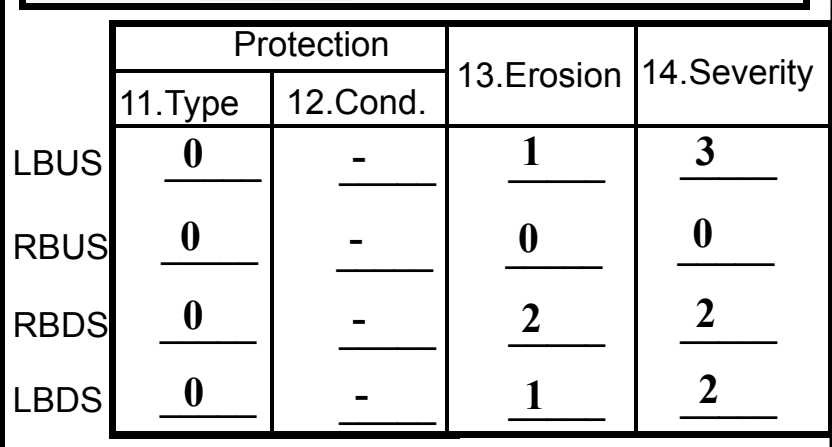

Bank protection types: 0- none; 1- $<12$ inches;

2- < 36 inches; 3- < 48 inches;

4- < 60 inches; 5- wall / artificial levee

Bank protection conditions: 1- good; 2- slumped;

3- eroded; 4- failed

Erosion: 0 - none; 1- channel erosion; 2 -

road wash; 3- both; 4- other

Erosion Severity: 0 - none; 1- slight; 2- moderate; 3- severe

\section{Channel approach to bridge (BF):}

15. Angle of approach: $\mathbf{3 0}$

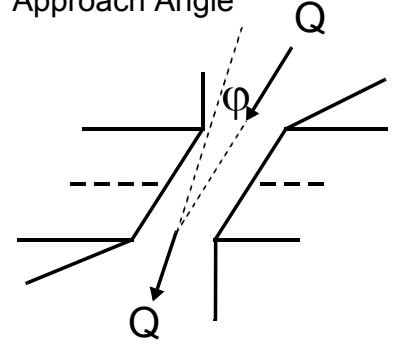

17. Channel impact zone 1:

Where? LB (LB, RB)

Range? 35 feet US

Channel impact zone 2:

Where? RB (LB, RB)

Range? $\underline{\mathbf{3 0}}$ feet $\underline{\mathbf{D S}}$

Impact Severity: 0- none to very slight; 1- Slight; 2- Moderate; 3- Severe
16. Bridge skew: $\mathbf{4 0}$ Bridge Skew Angle

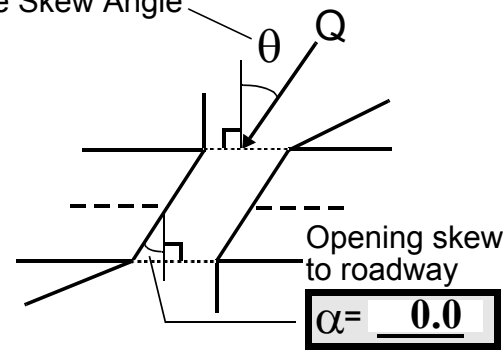

\section{Exist? $\mathbf{Y}(Y$ or $N)$}

Severity 3

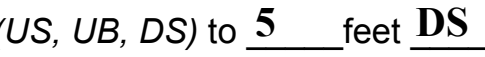

Exist? $\mathbf{Y}(Y$ or $N)$

Severity 2

$U B, D S)$ to $\underline{\mathbf{5 0}}$ feet $\underline{\mathbf{D S}}$ 
18. Level II Bridge Type: 1a

1a- Vertical abutments with wingwalls

$1 \mathrm{~b}$ - Vertical abutments without wingwalls

2- Vertical abutments and wingwalls, sloping embankment Wingwalls perpendicular to abut. face

3- Spill through abutments

4- Sloping embankment, vertical wingwalls and abutments

Wingwall angle less than $90^{\circ}$.

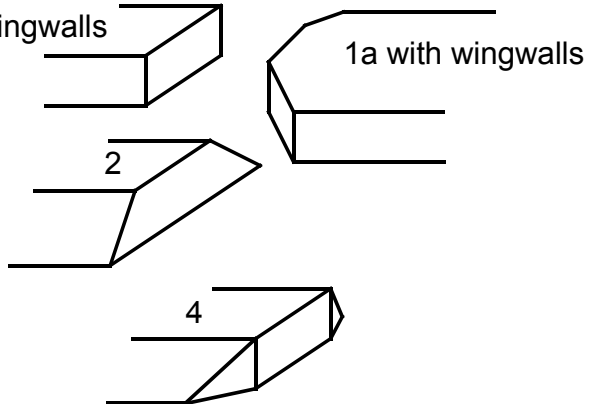

19. Bridge Deck Comments (surface cover variations, measured bridge and span lengths, bridge type variations, approach overflow width, etc.)

Measured bridge dimensions: bridge length=27 ft.; span length=21 ft.; roadway width=15 ft. The surface cover is all forest but the upstream right bank has a dirt road which parallels the stream. The left bank approach to the bridge is severely eroded and some protective measures have been taken (for lower regime high flows). Deck has recently been replaced, some rails and posts are missing.

\section{Upstream Channel Assessment}

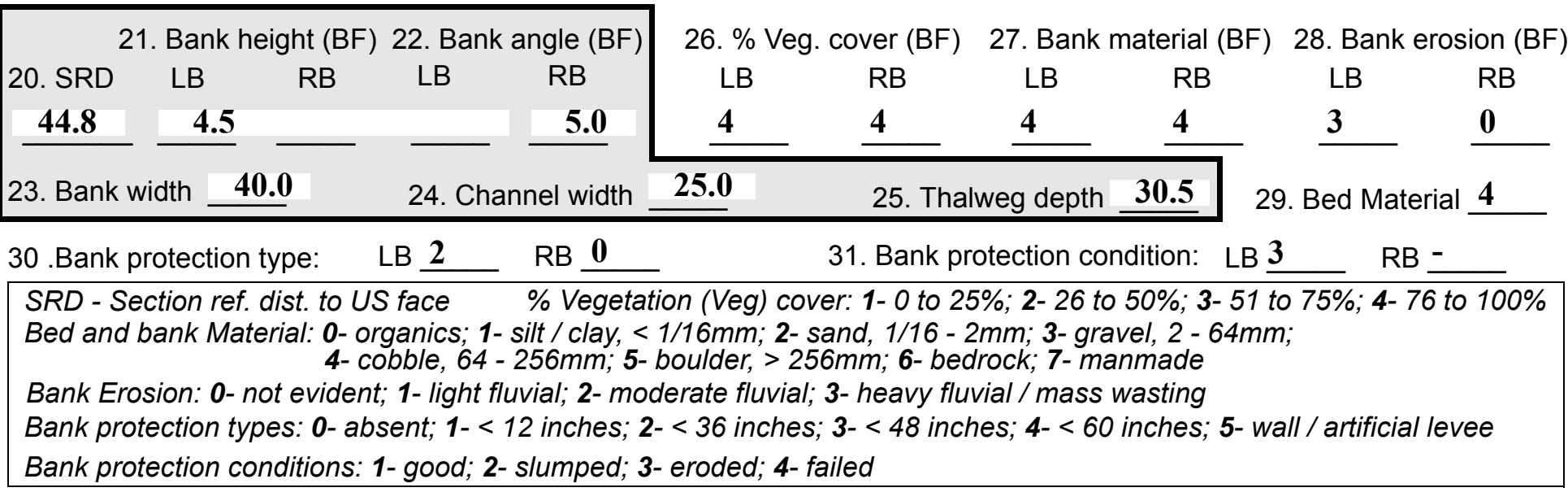

32. Comments (bank material variation, minor inflows, protection extent, etc.):

The left bank is protected only for low flows. The upstream left channel has a $20 \mathrm{ft}$. dry wall at the annual flood level which starts $30 \mathrm{ft}$. upstream of the bridge. The left bank near the bridge is severely eroded, even behind the upstream left wingwall and has, in the past, impacted the left road approach. The channel is not protected and flood flows would utilize the eroded channel. Small woody vegetation (birch) is present on the eroded area (5 year old growth). Natural material is piled in the channel at the upstream left abutment and upstream left wingwall (mostly cobbles). It looks like a point bar but appears to be placed. 

feet $\underline{\text { US }}$ (US, UB) to $\mathbf{5 0}$ feet $\underline{\text { US }}$

(US, UB, DS) positioned $\mathbf{6 0}$ \%LB to $100 \%$ RB

37. Material: 4

38. Point or side bar comments (Circle Point or Side; Note additional bars, material variation, status, etc.):

Another feature close to the upstream left wingwall and left abutment looks like a point bar but historical records and visual inspection indicate that it is very likely placed material.

39. Is a cut-bank present? $\mathbf{Y}$ (Y or if $N$ type ctrl-n cb)

41. Mid-bank distance: 15

42. Cut bank extent: $\mathbf{0}$

40. Where? $\underline{\mathbf{L B}}$ (LB or RB)

43. Bank damage: 1

(1- eroded and/or creep; 2- slip failure; 3- block failure)

44. Cut bank comments (eg. additional cut banks, protection condition, etc.):

The cut-bank is extensive along the left bank and is also double tiered. There is an active cut-bank at the annual flood level and an older cut-bank at a higher flood level. The older cut-bank would convey flood flows over the left road approach and erode behind the left abutment.

\section{Is channel scour present? $\mathbf{Y}$ (Y or if $N$ type ctrl-n cs) $\quad$ 46. Mid-scour distance: $\underline{30}$}
47. Scour dimensions: Length $\mathbf{5}$ Width 5
Depth : 0.5
Position $\underline{\mathbf{1 0}} \%$ LB to $\underline{\mathbf{2 0}} \%$ RB

48. Scour comments (eg. additional scour areas, local scouring process, etc.):

Scour is minimal but present along the cut-bank area.

49. Are there major confluences? $\mathbf{N}$

51. Confluence 1: Distance Confluence 2: Distance 52. Enters on Enters on 54. Confluence comments (eg. confluence name):

NO MAJOR CONFLUENCES
50. How many? -
53. Type- ( 1- perennial; 2- ephemeral)
Type - (1-perennial; 2- ephemeral) (1-perennial; 2- ephemeral) ( $(L B$ or $R B)$ (LB or $R B)$

\section{Under Bridge Channel Assessment}

55. Channel restraint (BF)? LB 2

56. Height (BF)
LB RB
$\mathbf{1 2 . 5}-$
58. Bank width (BF) -

59. Channel width (Amb) -

(1- natural bank; 2- abutment; 3- artificial levee)

Bed and bank Material: 0- organics; 1- silt / clay, < 1/16mm; 2- sand, 1/16 - 2mm; 3- gravel, 2 - 64mm; 4- cobble, 64 - 256mm; 5- boulder, > 256mm; 6- bedrock; 7- manmade

Bank Erosion: 0- not evident; 1- light fluvial; 2- moderate fluvial; 3- heavy fluvial / mass wasting

64. Comments (bank material variation, minor inflows, protection extent, etc.):

4

Bank is not protected but the upstream left wingwall and left abutment are partially protected by placed material. 
65. Debris and Ice Is there debris accumulation?

$(Y$ or $N)$ 66. Where? $\mathbf{N}$

(1- Upstream; 2- At bridge; 3- Both)

67. Debris Potential ( 1- Low; 2- Moderate; 3- High)

68. Capture Efficiency 2 (1- Low; 2- Moderate; 3- High)

69. Is there evidence of ice build-up? 1 ( $Y$ or $N)$

Ice Blockage Potential $\mathbf{N}$ (1-Low; 2- Moderate; 3- High)

70. Debris and Ice Comments:

1

One log is in downstream bank area; still not significant.

\begin{tabular}{|l|c|c|c|c|c|c|c|c|}
\hline Abutments & $\begin{array}{c}71 . \text { Attack } \\
\angle \text { (BF) }\end{array}$ & $\begin{array}{c}72 \text {. Slope } \angle \\
\text { (Qmax) }\end{array}$ & $\begin{array}{c}\text { 73. Toe } \\
\text { loc. (BF) }\end{array}$ & $\begin{array}{c}\text { 74. Scour } \\
\text { Condition }\end{array}$ & $\begin{array}{c}75 . \text { Scour } \\
\text { depth }\end{array}$ & $\begin{array}{c}\text { 76. Exposure } \\
\text { depth }\end{array}$ & 77. Material & 78. Length \\
\hline LABUT & & $\mathbf{4 0}$ & $\mathbf{9 0}$ & $\mathbf{2}$ & $\mathbf{2}$ & $\mathbf{0}$ & $\mathbf{1 . 0}$ & $\mathbf{9 0 . 0}$ \\
\hline RABUT & $\mathbf{1}$ & - & $\mathbf{9 0}$ & & & $\mathbf{2}$ & $\mathbf{0}$ & $\mathbf{2 1 . 0}$ \\
\hline
\end{tabular}

Pushed: $L B$ or RB

Toe Location (Loc.): 0- even, 1- set back, 2- protrudes

Scour cond.: 0- not evident; 1- evident (comment); 2- footing exposed; 3-undermined footing; 4- piling exposed; 5- settled; 6- failed

Materials: 1- Concrete; 2- Stone masonry or drywall; 3- steel or metal; 4- wood

79. Abutment comments (eg. undermined penetration, unusual scour processes, debris, etc.):

$\mathbf{0}$

1

The downstream end of the left abutment and the downstream left wingwall are have footings exposed to a depth of about $1.0 \mathrm{ft}$. The upstream left wingwall has slight footing exposure. Ambient flow attacks the left abutment and downstream left wingwall junction.

80. Wingwalls:

Exist? Material? Scour Scour Exposure Angle? Length? Condition? depth? depth?

USLWW:

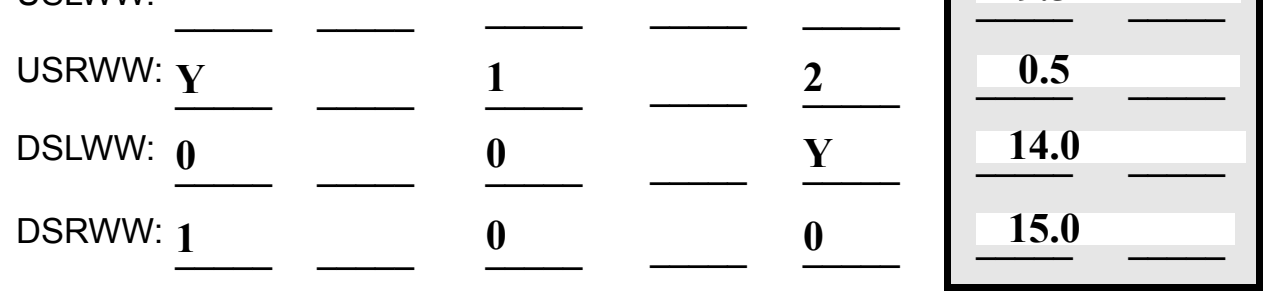

Wingwall materials: 1- Concrete; 2- Stone masonry or drywall; 3- steel or metal; 4- wood

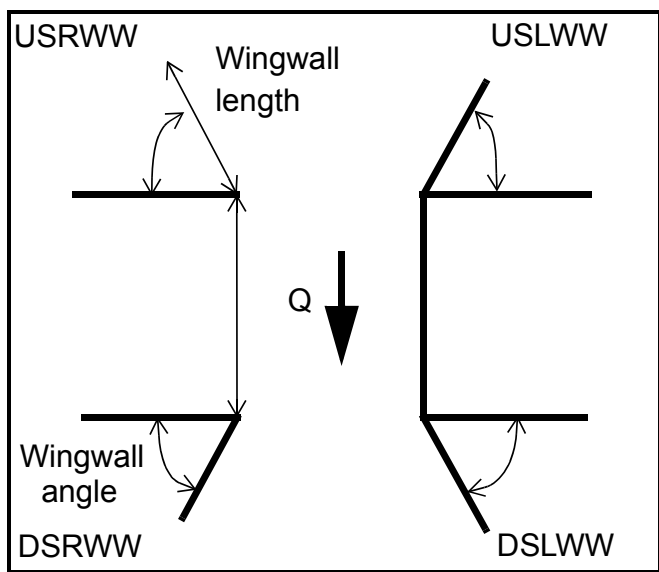

82. Bank / Bridge Protection:

\begin{tabular}{|l|l|l|l|l|l|l|l|c|}
\hline Location & USLWW & USRWW & LABUT & RABUT & LB & RB & DSLWW & DSRWW \\
\hline Type & - & $\mathbf{2}$ & Y & $\mathbf{0}$ & $\mathbf{2}$ & - & $\mathbf{3}$ & - \\
\hline Condition & $\mathbf{Y}$ & $\mathbf{0}$ & $\mathbf{1}$ & - & $\mathbf{1}$ & - & $\mathbf{4}$ & - \\
\hline Extent & $\mathbf{1}$ & $\mathbf{1 . 0}$ & $\mathbf{0}$ & $\mathbf{2}$ & $\mathbf{0}$ & $\mathbf{1}$ & $\mathbf{0}$ & $\mathbf{0}$ \\
\hline
\end{tabular}

Bank / Bridge protection types: 0- absent; 1- < 12 inches; 2- < 36 inches; 3- < 48 inches; 4- < 60 inches; 
83. Wingwall and protection comments (eg. undermined penetration, unusual scour processes, etc.):

$-$

$-$

0

$-$

$-$

0

-

0

0

\section{Piers:}

84. Are there piers? Un ( $Y$ or if $N$ type ctrl-n pr)

\begin{tabular}{|l|c|c|c|c|c|c|}
\hline \multirow{2}{*}{$\begin{array}{l}85 . \\
\text { Pier no. }\end{array}$} & \multicolumn{3}{|c|}{ width (w) feet } & \multicolumn{3}{|c|}{ elevation (e) feet } \\
\cline { 2 - 8 } & w1 & w2 & w3 & e@w1 & e@w2 & e@w3 \\
\hline Pier 1 & & & & $\mathbf{5 5 . 0}$ & $\mathbf{1 2 . 0}$ & $\mathbf{4 5 . 0}$ \\
\hline Pier 2 & $\mathbf{5 . 5}$ & $\mathbf{6 . 0}$ & $\mathbf{5 . 5}$ & $\mathbf{5 0 . 0}$ & $\mathbf{4 5 . 0}$ & - \\
\hline Pier 3 & - & - & - & - & - & - \\
\hline Pier 4 & - & - & - & - & - & - \\
\hline
\end{tabular}

\begin{tabular}{|l|l|l|l|l|}
\hline Level 1 Pier Descr. & \multicolumn{1}{|c|}{1} & \multicolumn{1}{|c|}{2} & \multicolumn{1}{|c|}{3} & \multicolumn{1}{|c|}{4} \\
\hline 86. Location (BF) & der & cob- & left & the \\
\hline 87. Type & brid & bles & abut & upst \\
\hline 88. Material & ge, & whic & ment & ream \\
\hline 89. Shape & the & h & , but & brid \\
\hline 90. Inclined? & left & pro- & most & ge \\
\hline 91. Attack $\angle$ (BF) & abut & vide & ly & face. \\
\hline 92. Pushed & ment & some & con- & \\
\hline 93. Length (feet) & - & - & - & - \\
\hline 94. \# of piles & has & pro- & strict & \\
\hline 95. Cross-members & "pla & tec- & s the & \\
\hline 96. Scour Condition & ced" & tion & flow & \\
\hline 97. Scour depth & nat- & to & thro & \\
\hline 98. Exposure depth & ural & the & ugh & \\
\hline
\end{tabular}

LFP, LTB, LB, MCL, MCM, MCR, RB, RTB, RFP

1- Solid pier, 2- column, 3- bent

1-Wood; 2- concrete; 3- metal; 4- stone

1- Round; 2- Square; 3- Pointed

Y-yes; $N$ - no

$L B$ or $R B$

0- none; 1- laterals; 2- diagonals; 3- both

0- not evident; 1- evident (comment);

2- footing exposed; 3- piling exposed;

4- undermined footing; 5- settled; 6- failed 
99. Pier comments (eg. undermined penetration, protection and protection extent, unusual scour processes, etc.):

$$
\begin{aligned}
& \text { N } \\
& - \\
& - \\
& -
\end{aligned}
$$

100.

\section{E. Downstream Channel Assessment}

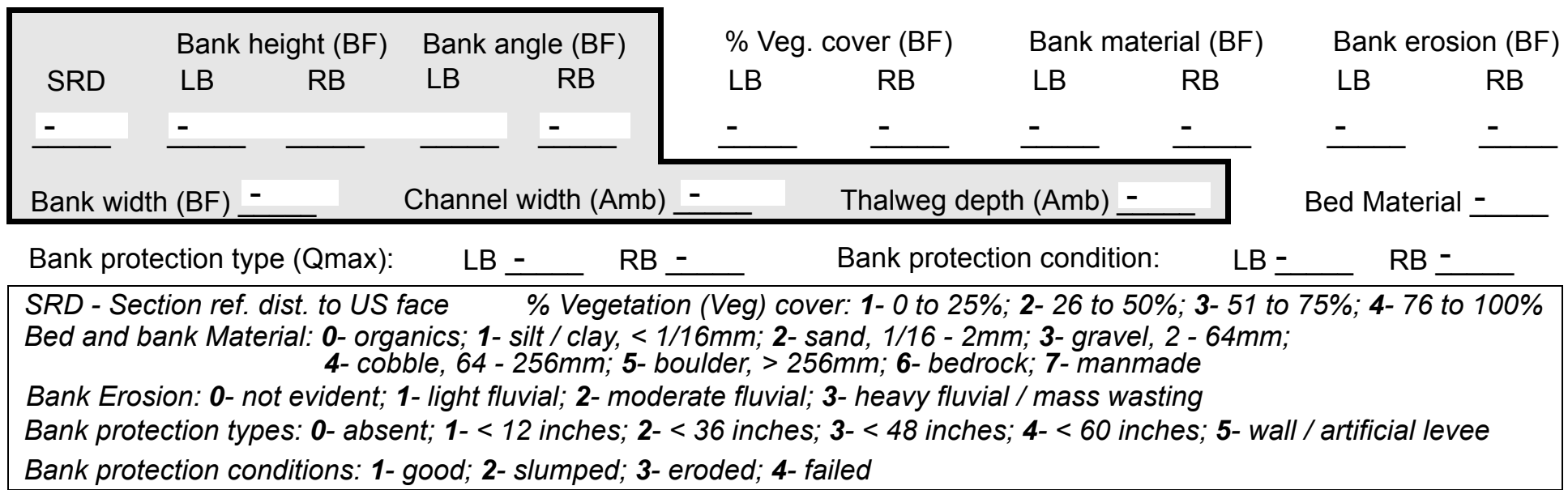

Comments (eg. bank material variation, minor inflows, protection extent, etc.):

-

\section{Is a drop structure present? __ ( $Y$ or $N$, if $N$ type ctrl-n $d s) \quad$ 102. Distance: ___ feet}

103. Drop: -_ feet 104. Structure material: ___ (1- steel sheet pile; 2- wood pile; 3- concrete; 4- other)

105. Drop structure comments (eg. downstream scour depth): 
106. Point/Side bar present? (Y or N. if N type ctrl-n pb)Mid-bar distance:

Mid-bar width:

Point bar extent: feet -

(US, UB, DS) to feet (US, UB, DS) positioned $\%$ LB to $\mathrm{NO} \% \mathrm{RB}$

Material: $\mathbf{P I}$

Point or side bar comments (Circle Point or Side; note additional bars, material variation, status, etc.):

ERS

Is a cut-bank present? ( $Y$ or if $N$ type ctrl-n cb) Where? (LB or $R B)$

Mid-bank distance:

Cut bank extent: feet (US, UB, DS) to feet 4 (US, UB, DS)

Bank damage: $\underline{4}$ ( 1- eroded and/or creep; 2- slip failure; 3- block failure)

Cut bank comments (eg. additional cut banks, protection condition, etc.): 4

4

3

3

$\underline{\text { Is channel scour present? }} \mathbf{4}$ (Y or if N type ctrl-n cs) Mid-scour distance: 0 Scour dimensions: Length $\underline{0}$ Width __ Depth: ___ Positioned The \%LB to left $\%$ RRB Scour comments (eg. additional scour areas, local scouring process, etc.):

bank is heavily eroded at the downstream left wingwall; material has slumped. The same condition exists locally along the left bank downstream; the right bank is severely eroded at the impact point about $40 \mathrm{ft}$. downstream. The bank is nearly vertical with large boulders and cobbles slumping into the channel near the toe of the slope.

Are there major confluences? ( $Y$ or if $N$ type ctrl-n $m c)$

How many?

Confluence 1: Distance Enters on (LB or $R B)$

Type (1- perennial; 2- ephemeral)

Confluence 2: Distance Enters on (LB or $R B)$

Type (1- perennial; 2- ephemeral)

Confluence comments (eg. confluence name):

\section{F. Geomorphic Channel Assessment}

107. Stage of reach evolution

1- Constructed

2- Stable

3- Aggraded

4- Degraded

5- Laterally unstable

6- Vertically and laterally unstable 
108. Evolution comments (Channel evolution not considering bridge effects; See HEC-20, Figure 1 for geomorphic descriptors):

$\mathbf{N}$

$-$

NO DROP STRUCTURE

Y

10

5

0

DS 


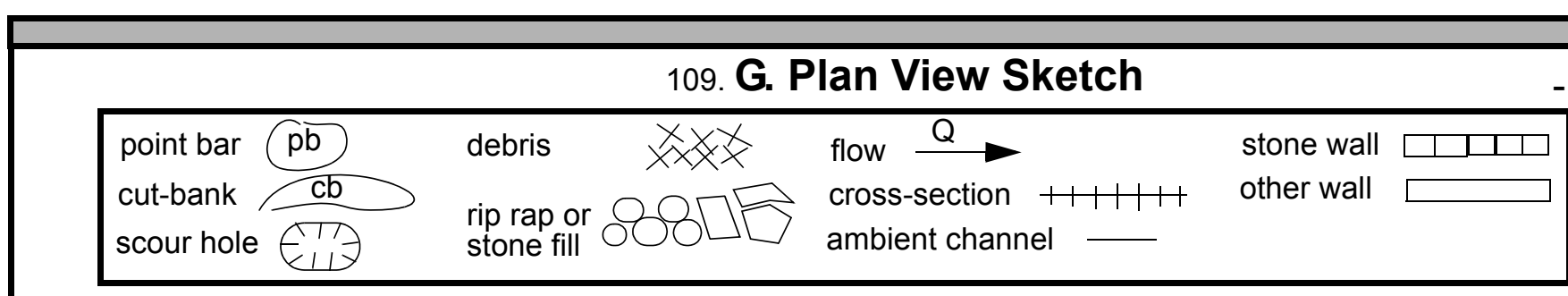

25 
APPENDIX F:

SCOUR COMPUTATIONS 


\begin{tabular}{|c|c|c|c|}
\hline \multicolumn{2}{|l|}{ Structure Number: BRIDTH00220015 } & Town: & Bridgewater \\
\hline \multicolumn{2}{|l|}{ Road Number: $\quad$ THOO22 } & County: & Windsor \\
\hline \multicolumn{4}{|l|}{ Stream: Dailey Hollow Branch } \\
\hline Initials SAO & & Checked: & \\
\hline \multicolumn{4}{|c|}{ Analysis of contraction scour, live-bed or clear water? } \\
\hline \multicolumn{4}{|l|}{ Neills Equation } \\
\hline \multicolumn{4}{|c|}{$\begin{array}{l}\mathrm{VC}=11.52 * \mathrm{y} 1 \wedge 0.1667 * \mathrm{D} 50^{\wedge} 0.33 \text { with } \mathrm{Ss}=2.65 \\
\text { (Richardson and others, } 1993, \mathrm{p} .31 \text {, eq. 14) }\end{array}$} \\
\hline \multicolumn{4}{|l|}{ Approach section } \\
\hline Characteristic & $100 \mathrm{yr}$ & $500 \mathrm{yr}$ & other $\mathrm{Q}$ \\
\hline Total discharge, cfs & 670 & 880 & 0 \\
\hline Main Channel Area, ft2 & 92 & 126 & 0 \\
\hline Left overbank area, ft2 & 0 & 0 & 0 \\
\hline Right overbank area, ft2 & 0 & 0 & 0 \\
\hline Top width main channel, ft & 28 & 36 & 0 \\
\hline Top width L overbank, ft & 0 & 0 & 0 \\
\hline Top width $\mathrm{R}$ overbank, ft & 0 & 0 & 0 \\
\hline D50 of channel, ft & 0.354 & 0.354 & 0 \\
\hline D50 left overbank, ft & 0 & 0 & 0 \\
\hline D50 right overbank, ft & 0 & 0 & 0 \\
\hline Y1, average depth, MC, ft & 3.3 & 3.5 & ERR \\
\hline y1, average depth, LOB, ft & $\mathrm{ERR}$ & ERR & ERR \\
\hline Y1, average depth, ROB, ft & $E R R$ & $E R R$ & ERR \\
\hline Total conveyance, approach & 4333 & 6398 & 0 \\
\hline Conveyance, main channel & 4333 & 6398 & 0 \\
\hline Conveyance, LOB & 0 & 0 & 0 \\
\hline Conveyance, ROB & 0 & 0 & 0 \\
\hline Percent discrepancy, conveyeance & 0 & 0 & ERR \\
\hline Qm, discharge, MC, cfs & 670 & 880 & ERR \\
\hline Q1, discharge, LOB, Cfs & 0 & 0 & ERR \\
\hline Qr, discharge, ROB, cfs & 0 & 0 & ERR \\
\hline Vm, mean velocity $\mathrm{MC}$, ft/s & 7.3 & 7.0 & ERR \\
\hline $\mathrm{Vl}$, mean velocity, LOB, ft/s & $\mathrm{ERR}$ & $\mathrm{ERR}$ & ERR \\
\hline Vr, mean velocity, $R O B, f t / s$ & ERR & $\mathrm{ERR}$ & ERR \\
\hline Vc-m, crit. velocity, $M C$, ft/s & 9.9 & 10.0 & $\mathrm{~N} / \mathrm{A}$ \\
\hline Vc-l, crit. velocity, LOB, ft/s & $\mathrm{N} / \mathrm{A}$ & $\mathrm{N} / \mathrm{A}$ & $\mathrm{N} / \mathrm{A}$ \\
\hline Vc-r, crit. velocity, ROB, ft/s & $\mathrm{N} / \mathrm{A}$ & $\mathrm{N} / \mathrm{A}$ & $\mathrm{N} / \mathrm{A}$ \\
\hline \multicolumn{4}{|l|}{ Results } \\
\hline Live-bed(1) or Clear-Water(0) Cont & action $s$ & our? & \\
\hline Main Channel & 0 & 0 & $\mathrm{~N} / \mathrm{A}$ \\
\hline Left Overbank & $\mathrm{N} / \mathrm{A}$ & $\mathrm{N} / \mathrm{A}$ & $\mathrm{N} / \mathrm{A}$ \\
\hline Right Overbank & $\mathrm{N} / \mathrm{A}$ & $\mathrm{N} / \mathrm{A}$ & $\mathrm{N} / \mathrm{A}$ \\
\hline
\end{tabular}


Clear water Contraction Scour in MAIN CHANNEL

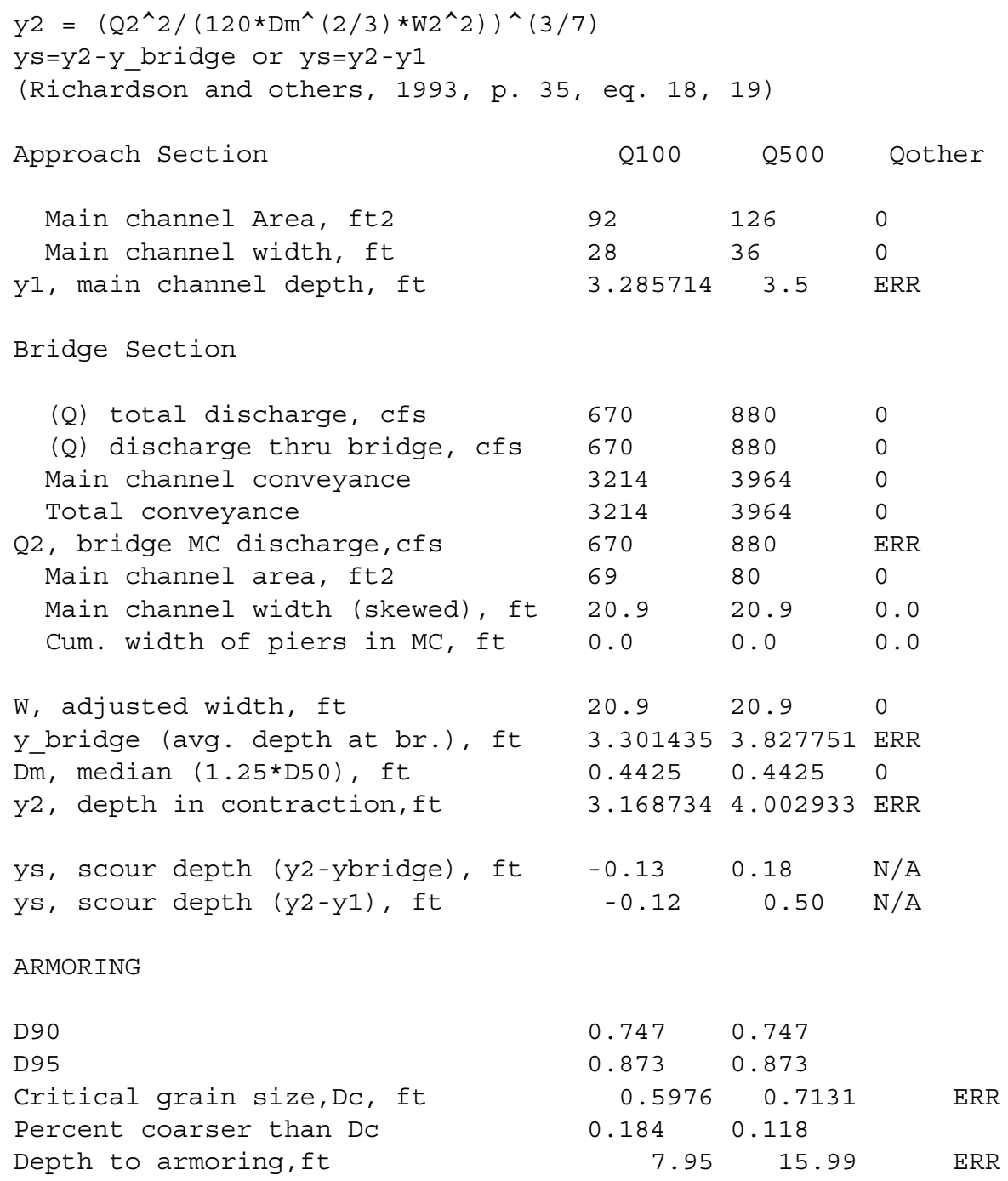


Abutment Scour

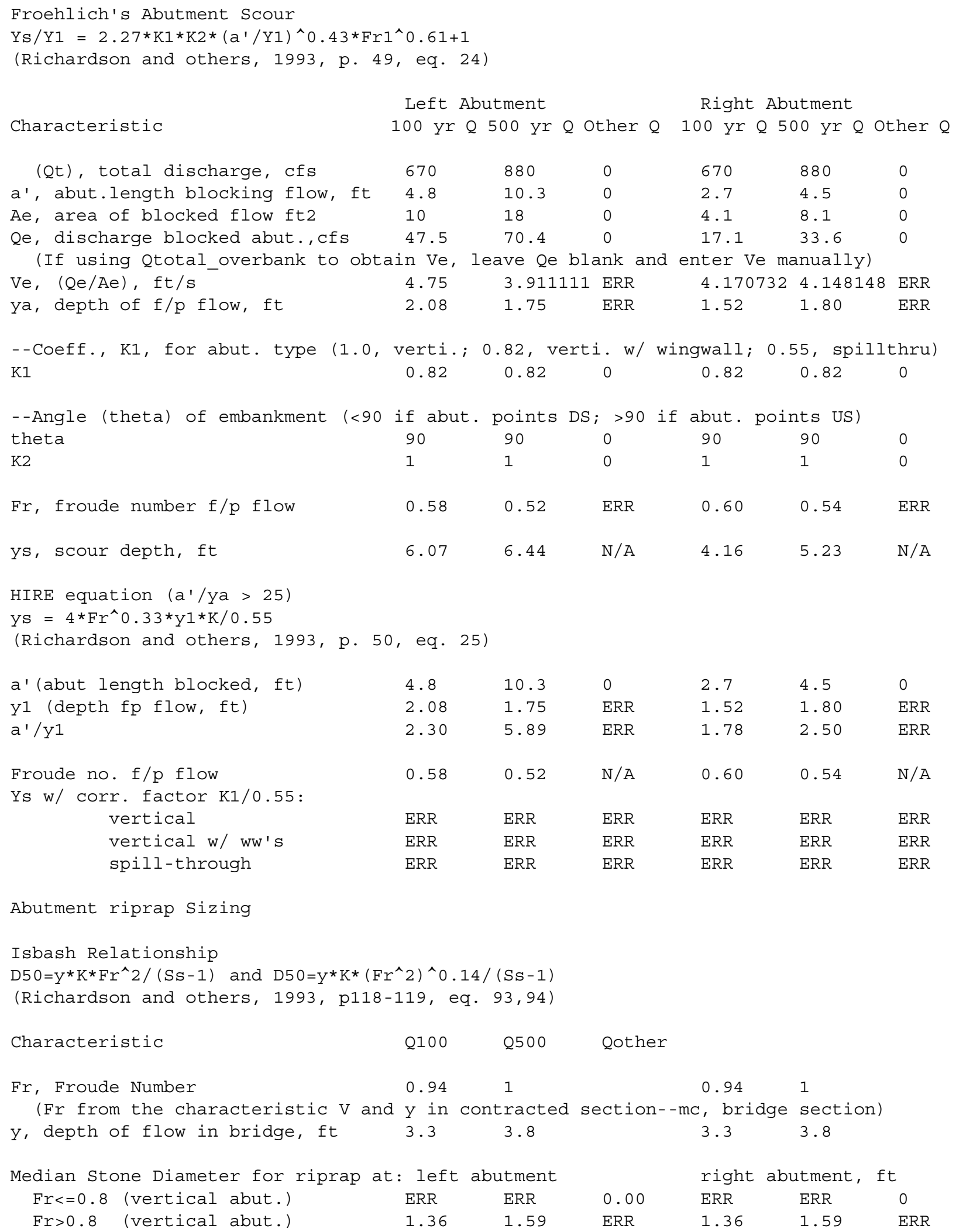


